\title{
XIII. Yüzyılda Güney Kafkasya’da Selçuklu İzleri: “Atabeglik Müessesesi ve Atabegler"
}

Ömer Subaşı*

\section{Özet}

Gürcistan Kraliçesi Tamara, Başkumandan Zakaria Mkhargrdzeli'nin 1212 yılındaki ölümünün ardından kardeşi İvane Mkhargrdzeli'ye başkumandanlık teklif etti. Bu teklif üzerine İvane, Kraliçe'den bir Selçuklu mirası olan ve neredeyse bölge devletlerinin tamamında kullanılan atabeglik unvanının kendisine verilmesini istedi. Gürcistan tarihinde o güne kadar eşine rastlanmayan bu unvanın talep edilmesine oldukça şaşıran Kraliçe, nihayetinde Ivane'ye atabeg unvanını vermeyi kabul etti. Bundan sonra adından çokça söz ettirecek, genellikle babadan oğula geçmek suretiyle varlığını sürdürecek olan bu unvan Güney Kafkasya siyasî hayatında boy göstermeye başladı. Mkhargrdzeli hanedanına mensup Atabeg Avak'ın ölümünden sonra atabeglik kurumunun Güney Kafkasya'daki temsilcileri Mankaberdeli ailesinin üyeleri oldu. XIII. yüzyılın sonlarına doğru sessizliğe bürünen atabeglik müessesesi XIV. yüzyılın başından itibaren Cakeli ailesinin yönetimi altındaki Atabegler Yurdunda kullanılmaya başlandı.

Bu çalışmada dönemin kaynakları göz önünde bulundurularak Selçuklu Devlet yapısının vazgeçilmez unvanlarından birisi olan Atabegliğin Güney Kafkasya siyasî hayatındaki yeri, önemi ve varoluş mücadelesi incelenecektir.

Anahtar Kelimeler: Güney Kafkasya, Selçuklu, Atabeg, Mkhargrdzeli, Mankaberdeli, Cakeli

\section{Seljukid Traces in South Caucasus in XIII. Century: "The Fact of Atabeg And Atabegs"}

\section{Abstract}

Tamara is the Queen of Georgia who proposed a commander-in-chief to his brother Ivane Mkhargrdzeli after the death of Commander-in-Chief Zakaria Mkhargrdzeli. According to the proposal, Ivane requested that the title of Atabeg, which is a Seljuk heritage from the Queen and used almost entirely in the region, should be given to him. The Queen surprised at the request of this title which was not found in the history of Georgia until that day, finally accepted to give Ivane the title of Atabeg. From this day forth,

\footnotetext{
* Yrd. Doç. Dr., Artvin Çoruh Üniversitesi, Fen-Edebiyat Fakültesi, Tarih Bölümü, subasi.omer25@gmail.com. (ORCID ID: 0000-0002-8081-6637)
}

(Makale Gönderim Tarihi: 11.05.2017, Makale Kabul Tarihi: 19.08.2017)

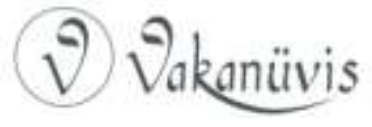


Ivane has his name rather frequently mentioned, and his title will continue its existence by passing from father to son, has begun to show up in the political life of South the Caucasus. After the death of Atabeg Avak, member of the Mkhargrdzeli dynasty, representatives of the Atabeg institution in the South Caucasus became members of the Mankaberdeli family. Towards the end of the XIII. Century, the fact of Atabeg which falls into silence, as from the beginning of XIV.century, Atabeg under the management of the Cakeli family began to be used in the country.

In this research is given the period that they are aware of the resources will be analyzed the importance and the struggle for existence in the South Caucasus political life which is one of the indispensable titles of the Seljuk State structure.

Keywords: South Caucasus, Seljuk, Atabeg, Mkhargrdzeli, Mankaberdeli, Cakeli

\section{Atabeglik Müessesesinin Ortaya Çıkışı ve Güney Kafkasya Siyasî Hayatındaki Yeri}

Ata ve beg kelimelerinden mürekkep olan bu kavram Türk kültüründe önceden beri bilinmektedir. Ancak siyasî ve hukukî mana kazanarak unvan ve müessese şeklinde ilk defa Selçuklular devrinde kullanılmıştır. Tarihi kaynakların verdiği bilgiler sayesinde atabegliğin Selçuklularda önemli bir vazife olduğu ve sonradan da yüksek bir unvan mahiyetini aldığı anlaşılmaktadır. Sultanlar, İmparatorluk topraklarının muhtelif parçalarını aile efradına dağıttıkları sırada henüz küçük yaşta olan meliklere vasi ve mürebbi sıfatı ile bir atabeg tayin ediyorlardı. Atabeg, yanında bulunan melikin terbiye ve öğretimiyle ilgilenir, eyaleti onun adına yönetirdi. Bunlar büyük vazifelerde bulunan eski ve nüfuzlu beylerden ya da değerli hizmetleriyle sadakat ve kudretlerini ispat etmiş, büyük emirlik derecesine yükselmiş askeri komutanlar arasından özellikle de Türk olmasına dikkat edilerek intihap olunuyordu. Sultan'ın güvenini kazanmış tecrübeli ve kudretli emirler arasından seçilen atabegler, herhangi bir teşvike kapılan meliklerin hükümdara karşı isyan çıkarmamaları için de onlara nezaret ederlerdi. Bu gibi emellere engel olmaya çalışan Atabeglerin ilk fırsatta öldürüldüğü, sonrasında meliklerin isyana kalkıştıkları da bilinmektedir. Ayrıca Atabeglerin dönem dönem Selçuklu iç siyasetine yön verdiği ve naibi bulunduğu meliki tahta çıkarmak, hakikatte ise devletin idaresini

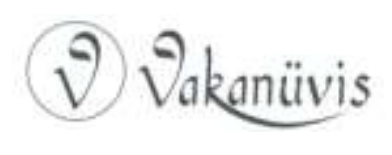


ele geçirmek için dâhili harplere sebebiyet verdikleri tarihi akış içerisinde görülebilmektedir. Önceleri bir unvan olarak ortaya çıkan ve zamanla önemli bir memuriyet şeklini alan atabeglik müessesesi, sonraları atabeglerin yanlarında bulunan meliklerin anneleriyle evlenmeleri veya kendi kızlarını meliklerle evlendirmeleri sebebiyle daha önemli bir mevki konumuna gelmiştir. ${ }^{1}$ Devlet içerisindeki ehemmiyetinden de anlaşıldığı gibi Selçuklularda bu müessesenin hususî bir karakterinin var olduğu, atabeg tabirinin sadece bir unvan olmadığı ve mühim bir vazife olduğu aşikârdır.

Selçuklularda bu unvanı ilk kullanan kişi meşhur devlet adamı Nizamülmülk'dür. Sultan Melikşah'ın (1072-1092) bütün işlerini tam bir istiklal ile Nizamülmülk'e bırakarak ve sair bazı unvanlarla beraber, atabeg unvanı verdiği iddia edilse de, Alp Arslan'ın Malazgirt savaşından sonra Nizamülmülk'ü oğlu Melikşah için Atabeg tayin ettiğine dair görüşler de mevcuttur. Nizamülmülk'ün askerî ricalden olmamasına rağmen atabeg olarak tayin edilmesi onun ehemmiyet ve nüfuzunu gösteren önemli bir nişanedir. Ancak atabeglerin umumiyetle büyük komutanlardan seçildiği unutulmamalıdır. ${ }^{2}$

Nizamülmülk'ün Melikşah tarafından ilk defa atabeg olarak atanmasıyla başlayan ve uzun yıllar Selçuklu siyasetine yön veren bu makam faal olarak kullanıldığı dönemlerde birçok şekilde karşımıza çıkmaktadır. Atabeglik müessesesinin Selçuklularda var olan kullanım alanlarına ana hatlarıyla benzerlik gösteren üç farklı şeklini özellikle Gürcistan ve Güney Kafkasya siyasî hayatında da görmek mümkündür.

Unvanın ilk kullanım şekli güçlü bir hükümdar veya sultanın devlet yönetimini genel hatlarıyla atabeg olarak tayin ettiği şahsa devretmesi usulüdür. Atabeg unvanı verilen şahsın sultanın idaredeki yetkilerini paylaştığı bu yöntem Melikşah ile Nizamülmülk örneğiyle kendisini göstermektedir. Selçuklularda Nizamülmülk örneği ile açıkladığımız ilk kullanım şeklinin Gürcistan'daki muadiline Kraliçe Tamara (1184-1213) ve Atabeg İvane arasındaki ilişkide rastlamaktayız. Kraliçe Tamara'nın bölgede kabul gören gücü ve otoritesinin yanında, askerî ve mülkî

\footnotetext{
${ }^{1}$ Coşkun Alptekin, "Atabeg”, C. I., DiA, s. 39; Halil İbrahim Gök, Musul Atabeyliği Zengiler (Musul Kolu 1146-1233), TTK. Yay., Ankara 2013, s. 430.

${ }^{2}$ M. Fuad Köprülü, “Ata”, C. I. İ.A., MEB. Yayınları, s. 712.
}

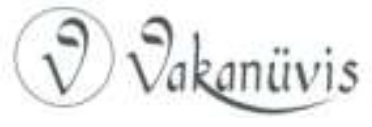


alandaki yetkilerini paylaştığı Atabeg İvane, dönemin tartışmasız en güçlü idarecisiydi. İvane, atabeg unvanıyla birlikte uzun yıllar başkumandan olarak görev yaptığı Gürcü ordularıyla önemli mücadelelere girişmiş, devamında Gürcü tarihi açısından mühim şahsiyetler arasındaki yerini almıştır. ${ }^{3}$

Selçuklularda belki de en geniş kullanım alanına sahip olan yöntem ise yaşı küçük Selçuklu meliklerinin bir bölgeye yönetici olarak gönderilmesi veya idareyi ele geçirdikten sonra ona yönetimde yol göstermesi amacıyla tayin edilen atabegin meydana getirmiş olduğu işleyiş şeklidir. Selçuklu Sultanı Berkyaruk'un (1092-1104) kardeşi Muhammed Tapar'ı (1105-1118) Gence'ye tayin ederek ona Emir Kutlug Tegin'i atabeg olarak görevlendirmesi veya Berkyaruk'un ölümüne yakın bir sırada oğlu Melikşah'ı veliaht ilan ederek ona Emir Ayaz'ı atabeg tayin etmesi, atabeg müessesesinin bu şekilde kullanımı için güzel birer örnektir. Küçük meliklerin vasi ve mürebbisi olan ve doğrudan doğruya büyük sultana bağlı bulunan bu atabegler, başında bulundukları geniş idarî sahanın adeta yarı müstakil bir hükümdar naibi mahiyetinde idiler; idarî, malî ve askerî bütün salahiyet onların ellerinde toplanıyordu. Ayrıca ölen atabegin yerine bazen oğlunun atabeg tayin edildiği görülür ki bu, ortaçağ Türk-i̇slam devletlerinde umumiyetle görülen bir prensip yani memuriyetlerin hemen hemen ırsi olması esasına bağlıdır. ${ }^{4}$

Gürcistan tarihinde bu tarz bir atabeglik müessesesine Kral II. Demetre (1271-1289) örneğinde rastlamak mümkündür. Küçük yaşta olmasından mütevellit devlet idaresinde yeterince tecrübesi bulunmayan Kral II. Demetre'ye devlet işlerinde yardımcı olması amacıyla Abaka Kaan tarafından Sadun Mankaberdeli atabeg olarak görevlendirilmişti. Abaka'nın Sadun'u yüksek bir rütbeye tayin etmesi aslında Kral'ı, Atabeg Sadun'un ellerine bırakmış, Atabeg ise kısa

\footnotetext{
${ }^{3}$ Kartlis Tskhovreba, (A History of Georgia), Trans.: Dmitri Gamq'relidze, Ed.: Roin Metreveli and Stephen Jones, Georgian National Academy of Sciences, Artanuji Publishing, Tbilisi 2014, s. 275-324.

${ }^{4}$ Köprülü, “Ata”, C. I. , s. 713.
}

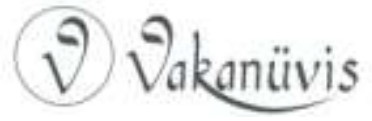


zamanda Gürcü coğrafyasının en güçlü isimlerinden birisi haline gelmiştir. $^{5}$

Selçuklu coğrafyasında var olan bir diğer atabeglik türü ise bulundukları bölgede hayatlarını sürdüren Selçuklu meliklerinin herhangi bir sebepten dolayı siyasî hayattan silinmelerinden sonra meliklere atabeg olarak görevlendirilen şahısların atabeg unvanını kullanarak devlet merkezinden yarı bağımsız şekilde yönetimi ele almasıdır.

Selçuklularda bu tarz bir idare şekli Dımaşk Atabegi Tuğtekin'in 1116 yılında Bağdat'ta Muhammed Tapar'dan Dımaşk ve çevresinin yönetimini ile atabeglik unvanını almasıyla karşımıza çıkar. ${ }^{6}$ Aslında 1104 yılında Dımaşk Meliki Dukak'ın (1095-1104) ölümünden 1116 yılına kadar gayri resmi atabeg olarak Dımaşk'ı idare eden; 1116 yılından itibaren de Tuğtekin'in bir Selçuklu meliki olmadan Dımaşk ve çevresinin yöneticisi olarak atabeg unvanını kullanması Selçuklularda yeni bir sürecin başlangıcı sayılabilir. Öyle ki XII. yüzyıl Selçuklu tarihinde birçok yarı bağımsız atabegliğin ortaya çıktığı bir dönem olarak da bilinmektedir. Bu dönemde Selçuklu Büyük Sultan'ın yani merkezi idarenin, nüfuzu devam ettiği müddetçe, atabeglerin açıktan açığa bir istiklal temayülü göstermeyecekleri ve devletin yüksek hâkimiyetini tanımak mecburiyetinde kalacakları tabii idi. Ancak Sultan Sencer'in ölümünden sonra atabeglerden birçoğu vasi ve naibi bulundukları Selçuklu meliklerinin yerine doğrudan doğruya kendi namlarına yönetimlerini icra etmeğe başladılar. Devamında Selçuklu sülalesine halef olan Atabegler denilen muhtelif sülaleler böyle teşekkül etti. Umumiyetle eski Selçuklu devlet teşkilatını devam ettiren atabegler sülaleleri yavaş yavaş kuvvetlendikten sonra, müstakil hükümdarlara mahsus daha mühim unvanlar da aldılar. Selçuklu siyasî

\footnotetext{
${ }^{5}$ illhanlılarda Atabeglik müessesesinin var olduğu bilinmektedir. Ancak bu konuya açıklık getirmek için çalışmalar yapan araştırmacılar ilhanlılarda bu mevzuya örnek olarak Olcaytu Sultan'ın oğlu Ebu Said için Emir Sevinç'i Atabeg olarak atadığı vakayı verirler. Ancak Emir Sevinç'ten çeyrek asır önce Sadun Mankaberdeli'nin Gürcü Kralı'na atabeg unvanı ile naip olarak tayin edildiği araştırmacıların gözünden kaçmıştır. Alptekin, “Atabeg”, C. I. 39.

${ }^{6}$ Abülkerim Özaydın, Sultan Muhammed Tapar Devri Selçuklu Tarihi (498-511/11051118), TTK Yay.; Ankara 1990, s. 136,137.

${ }^{7}$ Ali Sevim, Suriye ve Filistin Selçukluları Tarihi, TTK. Yay., Ankara 2000, s. 257.
}

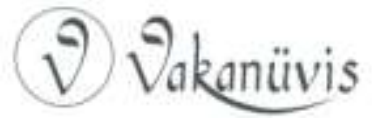


coğrafyasında Musul merkezli Zengiler, ${ }^{8}$ Fars'ta Salgurlular ${ }^{9}$ ve Azerbaycan'da illdenizliler ${ }^{10}$ böyle teşekkül etmiş birer siyasî yapılardır. ${ }^{11}$ Atabeglik müessesinin Güney Kafkasya siyasî hayatında en uzun süreli kullanılan tarzı işte bu yöntemdir. XIII. yüzyılın ikinci yarısından itibaren illhanlı Hükümdarı Abaka'ın (1265-1282) Tiflis merkezli Gürcü idarenin etki alanından ayırarak yarı bağımsız bir şekilde illhanlı merkezine bağladığı Samtskhe'nin yöneticisi Beka'ın 1308 yılındaki ölümünün ardından II. Sargis atabeg unvanını kullanmaya başladı. Samtskhe'de bu unvanın işlevsel hale getirilmesi Atabeg II. Sargis'in hâkimiyet sahasını uzun yıllar Saatabago (bssonsßszzm- Atabegler Yurdu) olarak anılmasına neden oldu. II. Sargis'den sonra Cakeli ailesinin atabegleri Gürcü idarî yapısından yarı bağımsız olarak yüzyıllarca bu bölgelerde hüküm sürdüler.

\section{Güney Kafkasya'da Atabeglik Müessesesi ve Atabegler: Mkhargrdzeli Hanedanı}

Selçuklular çağdaş birçok devleti idarî, malî ve askerî yönden etkilediği gibi onların bölgedeki Ortaçağ Hristiyan devletler üzerinde de tesirinin var olduğu bilinmektedir. Özellikle Atabeglik memuriyetinin ve unvanının Gürcü yöneticileri tarafından Gürcistan idarî yapısı içerisinde Selçuklu teşkilatı taklit edilerek kurulduğu, bu makamda bulunanların bütün dâhili işleri tıpkı Selçuklulardaki gibi idare ettikleri söylenebilir. ${ }^{12}$ XIII. yüzyılın başlarında Gürcü siyasî hayatında görülmeye başlanan atabeglik makamı genelde babadan oğula geçmekte olup Mkhargrdzeli, Mankaberdeli ve Cakeli isimli aileler tarafından siyasî hayatta işlevsel hale getirilmiştir.

\footnotetext{
${ }^{8}$ Musul Atabegi Nureddin Mahmud b. Zengi, Sencer'in ölümünün ardından Selçuklu Devletinin yıkılmasıyla bağımsızığını ilan etmiştir. Coşkun Alptekin, "Selçuklu Devletinin Askeri Teşkilatının Eyyubi Devleti Askeri Teşkilatına Tesiri", Belleten, LIV, S. 209, Ankara 1990, s. 118.

${ }^{9}$ Devletin başında sultan veya hükümdar yerine atabeg unvanını taşıyan bir hanedan azası bulunmaktaydı. Devletin idaresinin mutlak hâkimi o idi. Atabeg adına para basılır ve hutbe okunurdu. Ayrıca paralarda "atabeg"den başka unvan kullanılmazdı. Erdoğan Merçil, Fars Atabegleri Salgurlular, TTk. Yay. Ankara 1991, s. 125.

${ }^{10}$ ildenizliler hakkında bkz.: Ziya Bünyadov, Azerbaycan Atabegleri Dövleti, 1136-1225, Bakü 2007

${ }^{11}$ Köprülü, "Ata”, s. 714.

12 Köprülü, "Ata”, s. 716.
}

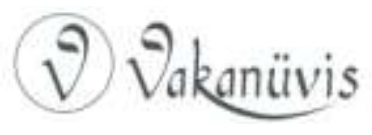


XII. yüzyılın sonlarına doğru Gürcistan'ın siyasî ve askerî hayatına

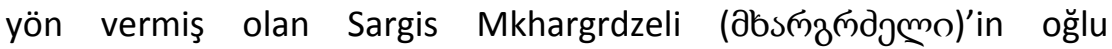
Başkumandan Zakaria Mkhargrdzeli 1212'de öldü. Zakaria'nın ölümü gerek Kraliçe Tamara gerekse Gürcüleri çok üzdü. O, Uzunkol Artakseres'ten ${ }^{13}$ gelmiş olup asalet ile bütün mtavarilerin ${ }^{14}$ üstünde ve en kıymetlisiydi. Zakaria'nın oğullarının küçük olmalarından dolayı Kraliçe, Zakaria'nın kardeşi Msakhuriler şefi unvanına sahip İvane'yi yanına çağırarak onu başkumandanlık unvanı ile kardeşinin mevkiine çıkarmak isteğini bildirdi. Buna çok şaşıran İvane, Tamara'ya: " Bana gösterdiğiniz hürmet benim gibi değersiz bir şahsın üstündedir. Kardeşimin adının benim şahsımla yad edilmesini rica ederim, zira onun yerini işgal etmekle utanırım. Bana bir iyilik lütfetmek istiyorsanız bana Atabeglik (sons8sz- Atabag) unvanını veriniz. Gürcistan krallarının huzurunda bir atabegin bulunması adet değilse de, diğer bütün unvanların üstünde olup sultanların huzurunda kullanılan bu unvanı bana lütfedin, çünkü atabeg, sultan ve kralların sütbabası demektir. Bu, bana karşı beslediğiniz sevginin nişanesi olsun." dedi. Kraliçe buna muvafakat ederek, Gürcistan krallarının hiçbir zaman kimseye vermemiş oldukları atabeg unvanını İvane'ye tevcih etti. Zakaria'nın oğlu Vahram'a ise Msakhuriler Şefi unvanı verildi. ${ }^{15}$

Aslında XIII. yüzyıla kadar başlıca dört büyük memur var iken 1212'de Kraliçe Tamara, bunlara beşinci olarak bir de Atabeglik ilave etmiş ki, askerî- idarî mahiyette bir vazife olmakla beraber, askeri

\footnotetext{
${ }^{13}$ Mkhargrdzeli ailesi ile alakalı olarak bkz. V. Minorsky, Studies in Caucasian History, London 1953, s. 102,103.

${ }^{14}$ Mtavari, Gürcü siyasi hayatındaki büyük asilzadeler veya soylu kişiler ile hanedan prenslerine verilen unvandır. Alexander Mikaberidze, Historical Dictionary of Georgia, Toronto 2007, s. 467.

${ }^{15}$ Kartlis Tskhovreba/Dmitri Gamq'relidze, s. 275; Marie F. Brosset, Gürcistan Tarihi, (Eski Çağlardan 1212 yılına Kadar), Çev.: Hrand D. Andreasyan, Not./Yay.: Erdoğan Merçil, TTK. Yay., Ankara 2003, s. 420; Smbat Sparapet's Chronicle, Trans.: Robert Bedrosian, Long Branch, New Jersey 2005, s. 101; Kirakos Gandzakets'i's, History of the Armenians, Trans.: Robert Bedroisan, New York 1986, s. 149; Müverrih Vardan, Türk Fütuhatı Tarihi, (889-1269), Çev.: Hrand D. Andreasyan, i.Ü.E.F.Y. Tarih Semineri Dergisi, C.I., Sayı: 2, İstanbul 1937, s. 219, 220; Stepannos Orbelean, History of the State of Sisakan, Trans.: Robert Bedrosian, Long Branch 2015, s.205; Stéphanos Orbélian, Histoire de la Siounie, Trans.: Marie F. Brosset, Saint- Petersbourg 1864, s. 225.
}

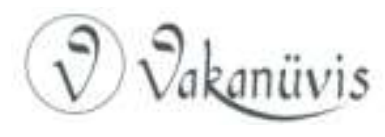


mahiyeti daha fazla idi. Bu dönemde Kral'dan sonra Kraliçe, Patrik, Başvekil ve Atabeg geliyordu. ${ }^{16}$ Atabeglik, idari hiyerarşinin en altında gösterilse de işleyişte bu makama sahip olan şahsın devletin en kudretli kişileri arasında olduğu bilinmektedir. Kraliçe tarafından atabeglik müessesesinin bir makam olarak kendinden üst bir pozisyonda Gürcü menşei olmayan birisine tevcih edilmesi dönemin şartları altında dahi büyük bir risk olarak düşünülebilir. Her ne kadar İvane, kardeşinin ismini kullanarak bu makamı Kafkasya'da işlevsel hale getirmiş olsa da bunun Kraliçe Tamara açısından bir anlam ifade etmediği muhakkaktır. Çünkü hâkimiyet süresi içerisinde Ahlat ve Erciş'ten Tebriz kapılarına kadar ordular sevk etmiş ve Rükneddin Süleymanşah (1196-1204) gibi kudretli bir Sultan'ı Micingirt'te yenilgiye uğratmış ayrıca IIldenizliler Atabegliği'ni sindirmiş ${ }^{17}$ bir Kraliçe için, kendisine bu başarıları sağlayan bir komutanına atabeglik unvanı vermesi an itibariyle siyasî bir manevradan başka bir şey değildir. Öyle ki Gürcü kroniğinin dediği gibi "Her taraf barış içinde idi ve Allah'ın himayesi altında bulunan Tamara'nın imparatorluğu günden güne refah içinde daha çok genişliyordu. ${ }^{118}$

Bünyesinde barındırdığı gücü kendisine bu başarıların yolunu açan birkaç komutanı arasında pay etmesi Kraliçe'nin iktidarını sarsmış olamazdı. Kraliçe yakın gelecekte düşmanlarından bir zarar gelmeyeceğini düşündüğünden olsa gerek hiç tereddüt etmeden Gürcistan siyasî hayatında Atabeglik kurumunu aktif hale getirdi. An itibariyle yapmış olduğu bu atamanın ülkesi için neler ifade ettiğini pekte öngöremedi; ancak kısa zaman sonra Gürcü Krallığı için ne kadar isabetli bir karar verdiği yaşanan olaylar sonrasında anlaşılacaktı.

Gürcü ileri gelenleri ve Mkhargrdzeli kardeşler Zakaria ve İvane, bir Selçuklu mirası olan Atabeglik müessesesinin gücünü ve kullanım alanlarını İldeniz'in 1160 yılında Irak ve Horasan Selçukluları Devleti'nin yeni hükümdarı olarak Arslanşah'ın büyük atabegi (atabeg el azam)

\footnotetext{
${ }^{16}$ Köprülü, “Ata”, C. I. I.A., , s. 717.

17 Kaynaklar Harezmşah Muhammed'in Özbek üzerinden Gürcistan Krallığına gönderdiği bir elçiden bahseder. Bu elçi, Azerbaycan'a yapılan saldırıların son bulması ve bu bölgenin artık bir Harezmşah ülkesi sınırları içerisinde olduğu yönündeki ikazını bildirmiştir. Coşkun Erdoğan, Hârezmşâh Alâeddin Muhammed Dönemi Siyasi Tarihi (1200-1220), Yayınlanmamış Doktora Tezi, AÜSBE, Erzurum 2015, s. 176.

${ }^{18}$ Kartlis Tskhovreba/Dmitri Gamq'relidze, s. 276; Brosset, Gürcistan Tarihi, s. 421.
}

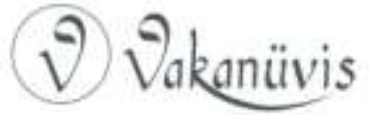


atandıktan sonraki siyasî olaylara nüfuzu ve Sultan üzerindeki etkisiyle tanıdılar. ${ }^{19}$ Çünkü Arslanşah'ın tahta geçmesini sağlayan en önemli etken üvey babası Atabeg illdeniz olmuştu. Bu güçlü Selçuklu emiri onu bir simge gibi kullanarak, kendi hâkimiyetini gerçekleştirmişti. ${ }^{20}$

Anonim Gürcü kroniğinde bazen yalnızca Atabeg bazen de Atabeg İvane olarak isminden sıkça söz ettiren ilk Gürcü Atabegi İvane'nin eline geçirmiş olduğu makamın hakkını vermesi gerekmekteydi. Atabeg, bunun farkındaydı ve hemen harekete geçip Kraliçe'nin kendisini görevlendirdiği Kafkasların kuzeyine yaptığı seferden başarıyla döndü ve yapılan bu görevlendirmenin ne kadar yerinde olduğunu Kraliçe'ye gösterir gibi tahrip ettiği yerleri sayarak gösterdi. ${ }^{21}$

Bu dönemde Kafkaslarda iki kişi Atabeg unvanını kullanmaktaydı. Illki Illdenizliler hanedanının son üyesi Atabeg Özbek (1210-1125), diğeri ise Gürcü devletinin önde gelen yöneticisi Atabeg İvane idi. ${ }^{22} 1213$ yılında Kraliçe Tamara'nın ölümünden sonra Gürcü tahtına IV. Giorgi Laşa (1213-1223) geçti. 1223 yılı itibariyle Gürcü Kralı́nın ölümüyle krallıkta kısa süreli varis sorunu yaşansa da IV. Giorgi Laşa'nın kız kardeşi Rusudan, Atabeg İvane'nin naipliğinde krallığın başına geçmişti. $^{23} 1212$ yılında Atabeg olarak atanan İvane 1227 yılındaki ölümüne kadar yaklaşık onbeş yıl bu makamı işgal etti. İvane, Gürcülerin hiçbir işini danışmadan yapmadıkları, en üst müracaat kaynağı ve yegâne başkumandanlarıydı. ${ }^{24}$ Atabeg İvane hayattayken oğlu Avak Başkumandan (amirsp'asalar), kardeşi Zakaria'nın

19 Ildeniz'in Büyük Atabeg olarak atanması hakkında bkz.: Bünyadov, Azerbaycan Atabegleri Dövleti, s. 39,40; İsmail Mehmetov, Türk Kafkası'nda Siyasi ve Etnik Yapı, Eski Çağlardan Günümüze Azerbaycan Tarihi, İstanbul 2009, s. 255; Gülay Üğün Bezer, "Şemseddin IIldeniz 1148-1175", I.A. C.22, s. 81-82.

${ }^{20}$ Hüseyin Kayhan, "Irak Selçukluları (1120-1194)", Yeni Türkiye, Ortadoğu Özel Sayısı III, C.3, S. 84, Ocak-Haziran 2016, s.80.

${ }^{21}$ Brosset, Gürcistan Tarihi, s. 421.

${ }^{22}$ Atabeg Özbek ve ildenizlilerin yıkılışı hakkında geniş bilgi için bkz.: Hüseyin Kayhan, "Azerbaycan Atabeyleri İldenizlilerin Yıkılışı", Tarih ve Gelecek Dergisi, Nisan 2017, C. 3, S. 1., ss. 239-255.

${ }^{23}$ Aknerli Grigor, Okçu Milletin Tarihi, Çev.: Hrand D. Andreasyan, Yeditepe Yay., İstanbul 2007, s. 22.

24 ibnü'l-Esîr, El Kâmil fi't-Tarih, C.X., (Terc. Heyet: Ahmet Ağırakça, Beşir Eryarsoy, Zülfikar Tüccar, Abdulkerim Özaydın, Yunus Apaydın, Abdullah Köşe), Hikmey Neşiryat, İstanbul 2016, s. 287.

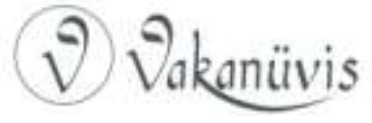


oğullarından Şehinşah, Mandatörlerin Şefi, ${ }^{25}$ diğer oğlu Gag Senyörü Vahram ise Msakhuriler Şefi ${ }^{26}$ idi. $^{27}$ Atabeg İvane'nin ölümümün ardından Ermenilerden alıp da Gürcüler için tamir ettirdiği Bakır Madenleri (Bege Netzahanak) ismindeki manastıra gömüldü. ${ }^{28}$ Atabeglik makamı ise Gürcü tarihinin gidişatını derinden etkilemiş olan oğlu Avak'a, başkumandanlık ise yeğeni Şehinşah'a geçti. Aslında bu geçişler Kraliçe Rusudan'ın izniyle mi gerçekleşti yoksa atabeglik, Mkhargrdzeli ailesi içerisinde babadan oğula geçen bir makam mıydı tam olarak bilemiyoruz. Ancak bir gerçek var ki tam da bu sırada Gürcülerin bu zamana kadar gördüğü en kudretli düşman olan Celaleddin Harezmşah, Gürcistan içlerinde istediği gibi faaliyet göstermekteydi. ${ }^{29}$

Gürcü siyasî hayatında bir asırdan fazla olayların akışına yön verecek olan Mkhargrdzeli ailesine mensup bireyler üzerlerine düşen görevleri yerine getirme gayretiyle yoğun çabalar sarf etmişlerdi. Aslında Atabeglik unvanını ilk kullanan kişi olması hasebiyle ìvane bu makamda bulunduğu dönem içerisinde birçok hadisenin önemli aktörleri arasında yer almış ancak ilk ve belki de en büyük sınavını Kral Giorgi Laşa ile birlikte 1220 yılının başlarında Moğollara karşı vermiştir. Doğudan gelen fakat Gürcülerin daha önce gördüğü rakiplerine hiç

\footnotetext{
${ }^{25}$ Mandatörler muhtemel merasimlerde görev yaparlar, reislerine ise MandaturtUkhutsesi idi. Brosset, Gürsitan Tarihi, s. 345; W.E.D. Allen, A History of The Georgian People, London 1932, s. 258.

${ }^{26}$ Msakhuri, belirli görevleri yerine getirmek için efendisine hizmet eden kişi veya yardımcı. Msakhurilerin şefine ise Msakhurt-Ukhetsesi denir. Grup içerisinde farklı kategoriler eşit haklara ve eşit sosyal pozisyonlara sahip olmamalarına rağmen yine de Msakhuriler belirli bir sosyal topluluğu ifade ederler. Kartlis Tskhovreba/Dmitri Gamq'relidze, s. 329; Allen, A History of The Georgian People, s. 228, 259.

27 İldeniz 1160 yılında Büyük Atabeg olarak Arslanşah'ın atabegi olarak atandığında devletin bütün kademesine kendi yakınlarını atamış: oğlu Cihan Pehlivan emir-hacip, küçük oğlu Kızıl Arslan hassa orduları başkomutanı, diğer emirlerini de çeşitli memuriyetlere getirmişti. Böylece Irak Selçukluları resmen İldenizlilerin eline geçmişti. Atabeg İvane'de Atebeg ildeniz'in devlet içindeki yapılanma yöntemini bire bir taklit ederek Gürcü siyasî hayatına derinlemesine nüfuz etmiştir. Mehmetov, Türk Kafkası'nda Siyasi ve Etnik Yapı, s. 255;

28 Müverrih Kiragos, Ermeni Müverrihlerine Göre Moğollar, Terc.: Gürsoy Solmaz, Ankara 2009, s. 23.

${ }^{29}$ Stepannos Orbelean/Bedrosian, s. 205; Stéphanos Orbélian/Brosset, s. 225.
}

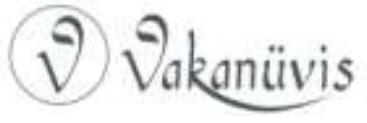


benzemeyen Moğolların karşısında rüştünü ispatlamaya gayret eden Atabeg İvane için bu süreç tam anlamıyla bir felaket olmuştur.

1220 yılında Sultan Muhammed Harezmşah'ın (1200-1221) İran'daki kaçışı sırasında onu takip ile vazifelendirilmiş olan Subutay Bahadır ve Cebe isimli generallerin ${ }^{30}$ komutası altındaki 20 bin kişilik bir Moğol ordusu ${ }^{31}$ Azerbaycan, Horasan ve Irak gibi bölgelerde herhangi bir direnişle karşılaşmadan ilerleyişlerini sürdürerek Gence önlerine kadar geldiler. Ardından yürüyüşlerine devam edip Gürcistan sınırlarına kadar ulaşarak Gag (Gugark) Bölgesi'ni tahrip etmeye başladılar. ${ }^{32}$

Gürcüler, ülkelerine girmeden önce istilacı Moğol kuvvetlerini karşılamak üzere asker sevk etmek için hayli ciddi hazırlıklara başlamışlardı. Bu sırada Gürcü Kralı IV. Giorgi Laşa, Azerbaycan ve Arran hâkimi Atabeg Özbek'e haber göndererek Moğolları geri püskürtmek ve onlara karşı birlikte savaşmak üzere anlaşma teklif etti. Aynı şekilde el-Cezire Emiri olan Melik el-Adil'in oğlu Melik el-Eşref'e de elçi göndererek bu ittifaklarına katılmasını istedi. Gürcüler gerek Özbek'e gerekse Melik el-Eşref'e 'Bu Moğollara karşı bizimle muvafakat etmediğiniz, bunları ülkelerimizden atmak üzere bizim gibi ordularınızın başında giderek bu mühim işi ele almadığınız ve Moğollara karşı birlikte savaşmamızı sağlamadığınız takdirde onlarla anlaşıp size karşı onlarla birlikte hücuma geçeriz." diyerek aslında kısa zaman sonra bir Gürcü dış politikası haline gelecek olan Gürcü-Moğol ittifakının temellerini zihinlerde atmış oldu. Bu sırada ittifak arama çalışmalarından herhangi bir sonuç elde edemeyince Moğollar ilk

${ }^{30}$ Cebe ve Subutay hakkında bkz., Saadettin Yağmur Gömeç, Türk Tarihinde Çingizliler, Ankara 2017, s 145-157.

${ }^{31}$ Vassâf bu ordunun 30.000 kişi olduğunu ifade eder. Şerefeddin Abdullâh b. İzzeddin Fadlullâh b. Ebû Nuaym Yezdî Şirazî Vassâf, Tahrîr-i Târîh-i Vassâf, Neşr.: Abdul Muhammed Ayetî, Institute for Humanities an Cultural Studies, Tehran 1383/2004, s. 303; Fasîh Ahmed b. Celaleddin Muhammed Hâfî, Mücmel-i Fasîhî, C. II., Neşr.: Muhammed Ferrruh, Meşhed 1340 (1961), s. 291; Cûzcânî, bu ordunun miktarını abartılı bir şekilde 60 bin olarak vermiştir. Ebu Ömer Minhacüddin Osman b. Muhammed b. Osman Cûzcânî, Tabakât-ı Nâsırî -Tarih-i Iran ve İslam-660/1262, C.II., Tsh.: Abdülhay Habîbî, Dünya-yı Kitab, Tahran 1984, s. 110; Erdoğan, Hârezmşâh Alâeddin Muhammed Dönemi, s. 253.

32 Kartlis Tskhovreba/Dmitri Gamq'relidze, s. 321; Marie F. Brosset, Histoire de la Géorgie, S.Petersbourg 1849, s. 492.

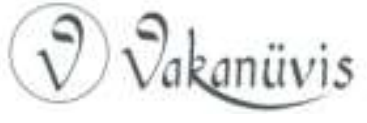


saldırılarında Tiflis'e kadar ulaştılar. Savaş sonrasında Gürcistan'ın dar geçitler ve yüksek dağlardan oluşan coğrafyasından dolayı daha ileri gidemeyerek geri dönmek zorunda kaldılar. Moğollar ile Gürcüler arasında meydana gelen bu ilk savaş H. 617 yılının Zilkade ayında (1220 Aralık - 1221 Ocak) vuku buldu. ${ }^{33}$ Yaşanan bu olaylar sırasında Gürcistan'ın asıl ordusu Tiflis'te idi. Moğolların ilerleyişinden haberdar olan Atabeg İvane ve Gag Prensi Vahram, Kral IV. Giorgi Laşa'ya bir mesaj göndererek; Moğol saldırıları sonucunda Somkheti bölgesinin yağmalandığını Kral’a bildirdiler.

Bunun üzerine Kral ve Atabeg İvane ve yeğeni Şehinşah, Gürcü Krallı̆̆ı'na ait süvari birliklerinin başında Gag'a, İvane'nin kardeşi Zakaria'nın diğer oğlu Vahram'ın yanına geldiler ve onu da yanlarına alarak krallığın bütün askerlerini toplayıp altmış bin atlıdan müteşekkil büyük bir ordu ile Gag Bölgesi'nde kamp kurmuş olan Moğollara karşı yürüyüşe geçtiler. ${ }^{34}$ Kral IV. Giorgi Laşa merkezde olmak üzere Atabeg İvane sol; Vahram ise sağ kanadı idare ediyordu (Recep 618-AğustosEylül 1221). Kanlı bir savaş yaşanırken yapılan ilk çarpışmalarda Moğollara karşı üstünlük sağlayan Gürcü ordusu içerisinde Atabeg İvane'nin de karıştığı bir tartışma, cinayet ile sonuçlandı ve bu olay Gürcü saflarında kargaşanın yaşanmasına neden oldu. Neticede Moğollar ile yapılan bu savaş Gürcülerin büyük zayiatı ile sonuçlandı. Kral ve Atabeg İvane, Tiflis'e kaçtı. Gag Senyörü Vahram da savaş alanını terk ederek Karherts adı verilen kalesine çekildi. Moğollar ise

${ }^{33}$ Gürcülerin bu elçileri geldiğinde, Melik el-Eşref, onlara verdiği cevapta Franklara karşı savaşmak üzere Mısır'a gitmek için hazırlıkları içinde olduğunu söyleyip özrünü açıklamış ve Ahlat bölgesini kardeşine ikta ettiğini, onun Moğollara karşı ihtiyaç duyulduğunda mutlaka yardım edeceğini beyan etmiştir. İbnü'l-Esîr, El Kâmil fi't-Tarih, C.X., s. 226,227, 249,250; Reşîdüddîn Fazlullâh-i Hemedânî, Câmi'u't-tevârîh 718/1318-, C. I., Yay. Haz.: Behmen Kerimî, İntişarat-ı İkbal, Tahran 1362/1983, s. 380; Reşideddin Fazlullah, Câmi'ü't Tevârîh, C.Il., Trans.: W.M. Thackston, Harvard Üniversitesi 1998, s. 259; R.J.C. Broadhurst, A History of the Ayyubid Sultans of Egypt, Translated from the Arabic of al Maqrizi, Boston 1980, s. 182; M. Baron C. D'ohsson, Moğol Tarihi, Çev./Yay./Haz.: Ekrem Kalan-Qiyas Şükürov, İstanbul 2006, s. 140; İbn Kesîr, El Bidâye Ve'n-Nihâye, C.XIII., Çev.: Mehmet Keskin, Çağrı Yay., İstanbul 1985, s. 196-205; Mîr Muhammed b. Seyyid Burhaneddin Havendşah Mîrhând, Târîh-i Ravzatü's-Safâ Fi Sireti'l-Enbiyâ ve'l-Mulûk ve'l-Hulefâ, 903/1498, Müessese-i Hayyam ve İntişarat-ı Piruz, Tahran 1339, C. V., s. 99.

${ }^{34}$ Anonim Gürcü Kroniği bu sayıyı doksan bin olarak verir. Kartlis Tskhovreba/Dmitri Gamq'relidze, s. 321; Brosset, Histoire de la Géorgie, s. 492.

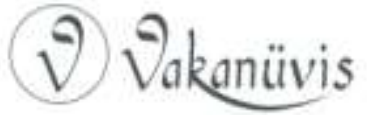


Gürcülerin bıraktıkları ganimeti toplayarak karargâhlarının bulunduğu Şamşvilde'ye taşıdılar. ${ }^{35}$

$\mathrm{Bu}$ olaydan sonra Moğollar Derbend geçini aşarak Kıpçak coğrafyasına geçtiler. Moğolların Gürcistan'dan ayrılmasından hemen sonra Kafkasların kuzeyinden gelerek Gürcü bölgesi'ne giren Kıpçaklar, Kral IV. Giorgi Laşa ve Atabeg İvane'ye başvurarak yurt edinebilecekleri bir yer isteyip karşılı̆̆ında ise Kral'a hizmet etmeyi teklif ettiler. Ancak ne Gürcü Kral ne de Atabeg İvane bu teklifi kabul etti. Kıpçaklar bu olumsuz cevap sonrası sık sık Gürcü baskısıyla karşılaşan Gence'deki Müslümanlara aynı teklifi yaptılar. Genceliler, teklifi kabul edip Kıpçakları Gürcülere karşı koymak üzere şehrin sınırlarına yerleştirdiler.

Kıpçakların Gence ve çevresinde iskân edilmeleri üzerinde endişeye kapılan Gürcü ileri gelenleri, bölgenin yeni yerleşimcilerine baskın düzenlemek üzere askerlerini toplayıp harekete geçtiler. Hem Kıpçakları hem de Gence halkını kâmilen imha edeceğini söyleyerek gurura kapılan Atabeg i̇vane, Gürcü ordularının başında Kıpçakların üzerine yürüdü. Gürcülerin bu hazırlıklarını haber alan Gence Emiri Kûşhâre, Kıpçakları bundan haberdar etti ve gelip Gence yakınlarında konaklamasını istedi. Kıpçaklar, Gence yakınlarına gelip karargâhlarını kurdular. Gence Emiri, Kıpçak Emirlerinin ileri gelen komutanlarından birisinin idaresinde Gürcüler üzerine bir ordu sevk etti. Kıpçaklar, Gürcüler üzerine yürüyüp onlara baskın düzenlediler. Gürcü askerleri harbe giriştikleri bir sırada Kıpçaklar saklandıkları yerlerden çıkarak onları kılıçtan geçirdiler. Gürcü ordusundan bir hayli adam öldürüp bakiyeleri de firara zorladılar. Ayrıca yanlarında bulunan malları da ganimet olarak alarak yakaladıklarını kılıçtan geçirip bir kısmını da esir aldılar. Gürcüler bu çatışmalardan mağlup çıkarken Kıpçaklar da karargâhlarına geri döndüler (1223). ${ }^{36}$

\footnotetext{
${ }^{35}$ Reşîdüddîn Fazlullâh/Behmen Kerimi, C. I., s. 381; Reşideddin Fazlullah/Thackston, C.I., s. 110 - C. II., s. 259; Mîrhând, Târîh-i Ravzatü's-Safâ, C. V., s. 101; Kartlis Tskhovreba/Dmitri Gamq'relidze, s. 321; Brosset, Histoire de la George, s. 493; Vardan, Türk Fütuhatı Tarihi, s. 222, 223; Aknerli Grigor, Okçu Milletin Tarihi, s. 21,22; Kiragos, Moğollar, s. 13,14; Histoire Chronologique, par Mkhithar D'airivank, XIII-S.,Traduite de L'armenien, Par Marie F. Brosset, St-Petersbourg 1869, s.105; A.G.Galstyan, Ermeni Kaynaklarına Göre Moğollar, (Mhitar Ayrivanetsi Vakayinamesi) Çev.: Illyas Kamalov, Yeditepe Yay., İstanbul 2005, s. 165; D’ohsson, Moğol Tarihi, s. 142.

${ }^{36}$ İbnü'I-Esîr, El Kâmil fi't-Tarih, C.X., s. 260, 261; Kiragos, Moğollar, s. 15.
}

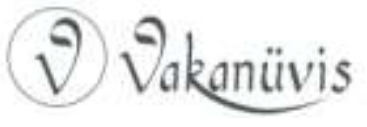


Kıpçakların, Atabeg İvane'nin sevk ve idaresindeki Gürcülere karşı elde ettikleri bu zaferden sonra diğer bir Kıpçak emiri de bir zafere nail olmak ve Gürcüleri mağlup etmek üzere harekete geçti. Bunu öğrenen Gence Emiri Kûşhâre, onu bu davranıştan alıkoymak üzere haber göndermiş ve Gürcülerin durumunu öğrenmeden böyle bir saldırıya geçmemesini istemişti. Fakat bu Kıpçak emiri, Kûşhâre'nin sözlerine kulak asmadan emrindeki askerleriyle Gürcüler üzerine yürüyüp memleketlerini yağmaladı ve birçok ganimet ele geçirirdi. Ancak yapılan ilk savaşta mağlup olan Atabeg İvane katledilen askerlerinin intikamını almak için yeniden kuvvet toplamış ve baskın için fırsat kollamaktaydı. Bu sırada Kıpçaklar yaptıkları yağma akınından geri dönerken, Gürcüler bildikleri bir yola girerek bu Kıpçak emirinden evvel geçidi tuttular. Kıpçaklar buradan geçerlerken onların üzerine saldırarak ani bir baskınla Kıpçak emiri ve adamlarını gafil avlayıp mağlubiyete uğrattılar. Gürcüler, Kıpçakları kılıçtan geçirmiş ve birçoğunu öldürüp ganimet olarak alınan mallarını tekrar geri almışlar, böylece Kıpçaklar da mağlubiyete uğramış olarak perişan bir şekilde geri dönmüşlerdi. ${ }^{37}$

Moğollar karşında herhangi bir varlık gösteremeyen Kral ve Atabeg, Kıpçaklarla giriştikleri mücadelenin hemen ardından Moğolların Azerbaycan ve Arran coğrafyasında sebep oldukları yıkımdan da nemalanmayı düşündüler. Ardından bir araya getirdikleri birlikler ile Moğollar tarafından büyük bir yıkıma maruz bırakılmış olan Beylakân'a saldırdılar. Bu sırada tamir ile meşgul olan halk üzerine taarruz ederek şehri ele geçiren Gürcüler, Müslümanları kılıçtan geçirmiş ve birçok kimseyi öldürmüş; Moğolların yaptığını fersahlarca geride bırakacak şekilde şehri yağmalamışlardı. ${ }^{38}$ Bu olayların akabinde 1223 yılının Ağustos-Eylül aylarında Ahlat'a bağlı Sürmârî (Sürmeli) kalesinin idarecilerinden birisinin Gürcü bölgelerine yaptığı akın sonrası Duvin

\footnotetext{
${ }^{37}$ Müverrih Vardan, Atabeg İvane'nin giriştiği ikinci seferi, ilk yenilgiden bir yıl sonra gerçekleştiğini iddia eder. Genceli Kiragos ise ilk savaştan birkaç gün sonra ikinci savaşın meydana geldiğini söyler. İbnü'l-Esîr, Kıpçakların Gürcülere karşı giriştikleri faaliyetleri 1222-1223 yılının olayları içerisinde ele almıştır. İbnü'l-Esîr, El Kâmil fi'tTarih, C.X., s. 260,261; Kiragos, Moğollar, s. 16; Galstyan, Sebastatsi Vakayinamesi, s. 41; Vardan, Türk Fütuhatı Tarihi, s. 223; M. Fahrettin Kırzıoğlu, Yukarı-Kür ve Çoruk Boyları'nda Kıpçaklar, TTK. Yay., Ankara 1992,, s. 144.

${ }^{38}$ Ibnü'l-Esîr, El Kâmil fi't-Tarih, C.X., s. 261,262.
} 
hakimi Şalva, Sürmârî kalesini muhasara ederek karşılık vermek istedi. Ancak sonraki girişilen mücadele sırasında Şalva esir olarak Sürmârî emirinin eline esir düşmüş ve Gürcü Kral'ın yoğun diplomatik çabaları sonrasında esaretten kurtarılmıştır. ${ }^{39}$

Kıpçak tehlikesinden bir an olsun kurtulduklarını düşünerek Beylakân'ı yağmalayıp Sürmârî emiri ile mücadeleye girişen Gürcüler, çok kısa bir süre sonra yeni ve daha büyük bir düşmanla karşılaştılar. Celaleddin Harezmşah, İran, Azerbaycan ve Arran Bölgesi'ni itaati altına aldıktan sonra 1225 yılının Mayıs ayında Atabeg Özbek'ten Tebriz'i alarak başkent yaptı ve küçük bir ordu ile Aras Nehri'ni geçerek Atabeg İvane ve yeğeni Mandatörlerin Şefi Şehinşah'a ait olan bölgelere geldi ve Duvin'i aldı. ${ }^{40}$ Ardından yoluna devam eden Sultan, Garni Deresi boyuna ulaştı. IV. Giorgi Laşa'nın ölümünden üç yıl sonra bölgeye gelen Harezmşahların, Duvin ve çevresini ele geçirmesi üzerine Atabeg İvane ve Gag Senyörü Vahram, Kraliçe Rusudan'ın yanına giderek ona Harezmşahların yavaş yavaş Gürcistan'a doğru yaklaştıklarını bildirdiler. Kraliçe bunu öğrenince krallığın bütün ordularını topladı ve Atabeg İvane'yi orduya başkomutan olarak tayin edip Sultan ile savaşması için gönderdi. Atabeg İvane 70 bin kişilik ordusu ile ilk önce Duvin'e, sonrada yoluna devam ederek Sultan'ın kamp kurduğu Garni Deresi'ne geldi ve bu mevkide Sultan ile savaşa tutuştu; ancak ağır bir yenilgi aldı. ${ }^{41}$ Atabeg İvane bu mağlubiyet sonrası perişan bir şekilde kaçtı. İvane kaçarken arkasından takip eden Sultan'ın askerleri peşini bırakmamış, nihayetinde İvane yanındaki on adamı ile kendi topraklarında bulunan müstahkem Geghe isimli

39 ibnü'l-Esîr, El Kâmil fi't-Tarih, C.X., s.265,266. Duvin hakimi Şalva için bkz. Ömer Subaşı, Gürcü-Moğol Iilişkisi- Güney Kafkasya 1220-1346-, Kitabevi Yay., İstanbul 2015, s. 42,43 .

${ }^{40}$ Kartlis Tskhovreba/Dmitri Gamq'relidze, s. 323.

${ }^{41}$ Kartlis Tskhovreba/Dmitri Gamq'relidze, s. 324; Brosset, Histoire de la Géorgie, s. 500; Vassâf, Târîh-i Vassâf, s. 320; Stepannos Orbelean/Bedrosian, s. 206; Şehabeddin Ahmed Nesevi, Celâlüttin Harezemşah, Çev.: Necip Asım, Devlet Matbaası, İstanbul 1934, s. 76; Mîrhând, Târîh-i Ravzatü's-Safâ, C.IV., s. 429; Alaaddin Ata Melik Cüveynî, Tarih-i Cihan Güşa, Çev.: Mürsel Öztürk, Kültür Bakanlığı Yay., Ankara 1999, s. 354356; Fasîh-i Hâfî, Mücmel-i Fasîhî, C. II., s. 298; Şihabeddin b. Fazlullah El-Ömerî, Mesâliku'l Ebsâr, -Türkler Hakkında Gördüklerim ve Duyduklarım-, (Çev.: Ahsen Batur) Selenge Yay., İstanbul 2014, s. 355, 356; Galstyan, Piskopos Stepanos Vakayinamesi, s. 64.

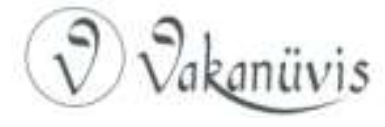


kalesine girip oraya kapanmıştı. ${ }^{42}$ Celaleddin, İvane'nin buradan çıkmasını engelleyecek bir miktar askeri kalenin muhasarası için ayırdıktan sonra geri kalan birliklerini Gürcü diyarına göndermiştir. ${ }^{43}$

Celaleddin, Beylekân, Gence, Duvin, Ani, Gag, Şamkor ve bütün Arran Bölgesi'ni zapt etmiş devamında Aralık 1225'te Tiflis'i kuşatmak için Gürcistan'a girmiştir. Kraliçe Rusudan, Sultan'ın yaklaşmakta olduğunu öğrendikten sonra Tiflis'i terk ederek Kutaisi'ye kaçmıştı. Sultan, ilk önce Somkheti'ye geldi ve bölgeyi ele geçirdikten sonra Tiflis'i kuşattı. Ardından üç aylık bir muhasaradan sonra 10 Mart 1226 'da şehri teslim aldı. ${ }^{44} 1226$ yılının Ağustos-Eylül aylarında Celaleddin yeniden harekete geçerek Gürcülerin elinde bulunan Ani kalesinin üzerine yürüdü. O sıralarda Ani kalesi Atabeg İvane'ye ait bölgeler arasında olup Celaleddin'in şehri kuşattığı sırada Atabeg İvane ile birlikte birçok Gürcü ileri geleni de kalede bulunmaktaydı. Celaleddin'in uzun ve şiddetli muhasarayla Atabeg ivane'yi kuşattığı bu sırada Kars kalesi üzerine de birlikler gönderdi. Bir süre bu iki kaleyi aynı anda kuşatan Celaleddin burada küçük bir birlik bırakarak bölgeden uzaklaştı. ${ }^{45}$

1227 Şubat-Mart aylarında Celaleddin'in şehirde olmadığı bir sırada Tiflis, yeniden Gürcülerin eline geçti. Bunu haber alan Sultan, Azerbaycan'dan Tiflis'e geri dönmek üzere yola çıktı. Sultan'ın gelmekte olduğunu öğrenen Kraliçe Rusudan, Mandatörlerin Şefi Şehinşah, Başkumandan Avak ve Gag Senyörü Vahram ile krallığın bütün ordularını topladı. Kraliçe, onları Harezmşahlar ile savaşmak için gönderdi. Gürcü ordusu hazırlıklarını tamamladıktan sonra Tiflis'ten

\footnotetext{
${ }^{42}$ Stepannos Orbelean/Bedrosian, s. 206.

${ }^{43}$ ibnü'I-Esîr, El Kâmil fi't-Tarih, C.X., s. 287.

${ }^{44}$ Reşîdüddîn Fazlullâh/Behmen Kerimi, C. I., s. 395; Reşideddin Fazlullah/Thackston, C. II., s. 269; Cüveynî, Tarih-i Cihan Güşa, s. 354-356; Mîrhând, Târîh-i Ravzatü's-Safâ, C. IV., s. 427, 428; Nesevi, Celâlüttin Harezemşah, s. 70, 71; Kartlis Tskhovreba/Dmitri Gamq'relidze, s. 325,326; Brosset, Histoire de la Géorgie, s. 497, 498; İbnü'l-Esîr, El Kâmil fi't-Tarih, C.X., 302-306; Vardan, Türk Fütuhatı Tarihi, s. 224; Kiragos, Moğollar, s. 16, 17; Kırzıoğlu, Kıpçaklar, s. 145; Cûzcânî, Tabakât-ı Nâsırî, C.I., s. 316, 317; Ebu Ömer Minhacüddin Osman b. Muhammed el-Cüzcani, Tabakat-ı Nasıri: from A.H. 194 (810 A.D.) to A.H. 658 (1260 A.D.) / Maulana Minhaj-ud-din Abu-Umar-I-Usman; translated by Major H. G. Raverty, New Delhi 1970, s. 295, 296; Galstyan, Sebastatsi Vakayinamesi, s. 42, 64, 165; Vassâf, Târîh-i Vassâf, s. 320.

${ }^{45}$ Ibnü'l-Esîr, El Kâmil fi't-Tarih, C.X., s. 311.
} 
ayrıldı. Bu sırada Sultan ve ordusu Somkheti'de kamp kurmuştu. Yapılan kısa süreli bir çarpışma sonrası Sultan, Gürcüleri geri çekilmeye zorladı devamında Tiflis'e geldi ve şehri yeniden ele geçirdi. Geride kalan Gürcüler, şehri Celaleddin'e karşı koruyamayacaklarını bildiklerinden dolayı Tiflis'in her tarafını ateşe verip bölgeden hızlıca uzaklaştılar. ${ }^{46}$ Sultan'ın, Gürcistan coğrafyasındaki son savaşı yine Atabeg İvane ile Lori Şehri yakınlarında H.625 (1227-28) yazında yaşandı ve Sultan giriştiği savaşta Gürcüleri ağır bir yenilgiye uğrattı. ${ }^{47}$

Stepannos Orbelean tarafından 1227 yılında öldüğü iddia edilen Atabeg İvane'nin Sultan ile giriştiği Lori savaşından kısa zaman sonra öldüğü muhtemeldir. Ayrıca Anonim Gürcü Kroniği, İvane'nin ölümü hakkında tarih vermese de Celaleddin Harezmşah ile 1225 yılında yapılan Garni Savaşı'ndan yaklaşık iki yıl sonra öldüğünü ifade etmesi Stepannos'un verdiği bilgileri doğrular ve tamamlar niteliktedir. ${ }^{48}$ Atabeg İvane'den sonra oğlu Başkumandan Avak, Atabeg unvanını aldı ve 1250 yılındaki ölümüne kadar yaklaşık 23 yıl gibi uzun bir süre bu makamı işgal etti. ${ }^{49}$

Avak'ın atabeglik makamında bulunduğu süre Gürcü tarihinin eşine az rastlanır dönemlerinden birisine denk gelmektedir. Çünkü Ögeday Kaan'dan (1229-1241) alınan bir emirle Cormagon (CarmaganCarmagon-Çarma Han), Benal ve Mular (Molar-Molur-Moğar) isimli üç reis Kafkaslara yapılan ilk Moğol akınından yaklaşık on yıl sonra

\footnotetext{
${ }^{46}$ İbnü'l-Esîr, El Kâmil fi't-Tarih, C.X., s. 321; Vassâf, Târîh-i Vassâf, s. 321; Nesevi, Celâlüttin Harezemşah, s. 78; Kartlis Tskhovreba/Dmitri Gamq'relidze, s. 329.

${ }^{47}$ Cüveynî, yaşanacak mücadele öncesinde Atabeg İvane ile Sultan Celaleddin arasında geçen ilginç bir vakadan bahseder. Müellife göre "Gürcü ordusunun savaş düzenine geçmesinden sonra Celaleddin, Gürcülerin komutanı ivane'ye bir elçi göndererek "Siz uzaktan geldiniz. Siz ve atlarınız yorgunsunuzdur. Bugün savaş yapmayalım. Yalnız, sizden ve bizden yiğitler çıkıp meydanda dövüşsünler, biz de onları seyredelim." diye haber gönderdi. Bu fikir Ivane tarafından da kabul edilince sıra dövüşecek olanları seçmeye geldi. Gürcüler tarafından dağ gibi cüssesi olan genç bir pehlivan, ona karşı da Münker gibi olan Sultan meydana çıktı." Cüveynî, Tarih-i Cihan Güşa, s. 362-365; Vassâf, Târîh-i Vassâf, s. 321; Nesevi, Celâlüttin Harezemşah, s.112.

${ }^{48}$ Kartlis Tskhovreba/Dmitri Gamq'relidze, s. 324; Piskopos Stepanos, Atabeg İvane'nin ölümünü 1227 yılı olarak verir. Galstyan, Piskopos Stepanos Vakayinamesi, s. 65; Atabeg İvane, Genceli Kiragos'a göre ise 1241 yılında ölmüştür. Bedrosian, Kirakos Ganjakets'i's, s. 185

${ }^{49}$ Stepannos Orbelean/Bedrosian, s. 205, 212.
}

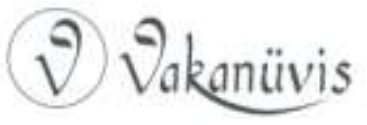


yeniden Arran ve Gürcü memleketleri üzerine yürüyerek birçok şehir ve kaleyi ele geçirdiler. ${ }^{50}$ Harezmşah tehlikesi ortadan kalktıktan sonra meydana gelen Moğol istilası Gürcistan'dan önce Azerbaycan Bölgesi'ni vurdu. ${ }^{51}$ Devamında Moğollar, Ermenistan, Gürcistan ve Arran Bölgesi'ni dağ ve ovaları da dâhil olmak üzere kısım kısım aralarında paylaştılar. ${ }^{52}$ Bu bölüşme sırasında dört önemli reis Likhi Dağları'nın doğusundaki Gürcistan Kralığı'nın tamamını aralarında bölüştüler. ${ }^{53}$ Bunlar arasında Çağatay, Şehinşah'a ait olan Lori Şehri ve civarını; ${ }^{54}$ Dolada Noyan, Atabeg Avak'ın yakalanmasından sonra ona ait olan Gayan-Keyan (Kayen-Caen) Kalesi'ni aldı. Mular Noyan Vahram ve oğlu Ak-Boğa'ya ait olan eyaletleri ve kaleleri zapt etti. ${ }^{55}$ Cormagon ise Ani ve Kars Bölgesi ile etraftaki yerleri alarak büyük mekânı da önce tahrip edip daha sonra yeniden imar ettirdiği Gence şehrine nakletti. ${ }^{56}$

Güney Kafkasyada yaşanan bütün bu kargaşa ve karışıklıklar sırasında Moğol-Gürcü ilişkisinde dönüm noktası olarak görülebilecek bir vaka meydana geldi. Moğollar ile Gürcüler arasındaki savaşları durdurup devamında müttefik olmalarının yolunu açan ve onlarla ilk barışı yapan şahıs Atabeg Avak oldu. Atabeg Avak, iki taraf arasında herhangi bir anlaşma olmadan daha önce bütün memleketlerin

${ }^{50}$ Kartlis Tskhovreba/Dmitri Gamq'relidze, s. 329; Stepannos Orbelean/Bedrosian, s. 207, 208.

${ }^{51}$ Moğol istilasının Azerbaycan üzerindeki etkisi için bkz. Bayram Arif Köse, "Moğol İstilasının Güney Kafkasya Şehirleri Üzerinde İdarî ve İktisadî Etkileri", Uluslararası Sosyal Araştırmalar Dergisi, C.8. S. 41. 2015, s. 486-498.

52 Robert Bedrosian, Het'um the Historian's History of the Tartars, [The Flower of Histories of the East] compiled by Het'um the Armenian of the Praemonstratensian Order Translated by Robert Bedrosian, Long Branch, New Jersey, 2004, Capter 18, s. 38; Kiragos, Moğollar, s. 21; Peter Jackson, The Mongols and The West, 1221-1410, Great Britain 2005, s. 39, 40; Muhammed b. Ali b. Muhammed b. Şabânkâreî, Mecmaû'l-ensâb, Neşr.: Mîr Hâşim-i Muhaddis, Tahran 1376, s. 250; Cûzcânî, TabakâtI Nâsırî, C.Il., s. 153, 158; Gregory Abû'l Farac, Abû'l-Farac Tarihi, C.II., Süryaniceden Çev.: Ernest A. Wallis Budge, Türkçe Yay.: Ömer Rıza Doğrul, TTK. Yay., Ankara 1999, s. 526; Kartlis Tskhovreba/Dmitri Gamq'relidze, s. 330.

${ }^{53}$ Allen, A History of The Georgian People, s. 113.

${ }^{54}$ Kiragos, Moğollar, s. 32.

${ }^{55}$ Kiragos, Moğollar, s. 25.

${ }^{56}$ Vardan, Türk Fütuhatı Tarihi, s. 225, 226; Aknerli Grigor, Okçu Milletin Tarihi, s. 22; Galstyan, Ermeni Kaynaklarına Göre Moğollar, (Harput Şehrindeki Incil'de Yazılan Hatıra Notundan Alıntı), s. 85; Kiragos, Moğollar, s. 21.

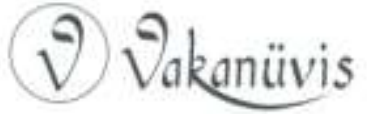


uğradığı istilayı görerek müstahkem Gayan-Keyan isimli kalesine kapanmıştı. ${ }^{57}$

Moğollar, Avak'ı saklandığı kalede muhasara ettikten sonra teslim olmaya zorladılar. Atabeg Avak bu sırada noyanların ileri gelenlerinin bulunduğu Berda'a (Bordav)'a bir elçi göndererek Cormagon'a başvurup teslim olmak istediğini; Moğollara hizmet etmeyi ve toprakları için onlara haraç vermeyi kabul ettiğini bildirdi. Moğollar, Avak'ın bu mesajlarını sevinçle karşıladılar. Ardından teslim olan Avak, Kefargunik (Sevan Gölü) Denizi kenarında ordugâh kurmuş olan General Cormagon, Çağatay ve Baycu'nun yanına götürüldü. Burada Cormagon ile Avak arasında gelişen iyi ilişkilerinin bir sonucu olarak Avak'ın, Moğol noyanının başlıca ümerası arasına girecek kadar günden güne itibarı arttı. Cormagon, Avak'a evvelce sahip olduğu arazisini iade etmekle kalmadı; daha fazla yerler de ilave etti. ${ }^{58}$

Gürcüler ile Moğollar arasındaki ilişkilerin gelişerek devam ettiği bir sırada Atabeg Avak, kuzeydoğuda ikamet etmekte olan Ögeday Kaan'ın yanına gitmek üzere yola çıktı ve sadece boyun eğmeyi arz etmek maksadıyla geldiğini söyleyerek Kaan'ın dostluğunu kazanmaya gayret gösterdi. Kaan, Avak'ı dinledikten sonra onu dostane bir suretle kabul etti; kendisine zevce olarak bir Moğol kızı verdi ve memleketini iade etti. Aynı zamanda henüz mukavemet eden Gürcü ileri gelenleri de onun yardımıyla itaat altına almaları için generallerine bir mektup yazdı. Bu sırada Gürcü soyluları ise bir taraftan müstahkem mevkilerinde kendilerini güçlendirmekle meşgul olurken bir taraftan da Moğollara itaat etmek için pazarlık yapmaya başlamışlardı. ${ }^{59}$ Moğol saldırılarından bıkıp usanan Gürcü ve Ermeni Prensleri, Atabeg Avak'ın teşviki ile barış imzalayarak Moğol hâkimiyeti altına girmeyi kabul ettiler. $^{60}$

Ancak dostane ilişkiler kısa sürdü ve Atabeg Avak, yaşanan bir olay sonrasına öldürülmekten korktuğu için kurtuluşu Moğollarla mücadele

\footnotetext{
${ }^{57}$ Kartlis Tskhovreba/Dmitri Gamq'relidze, s. 331; Brosset, Histoire de la Géorgie, s. 514, 515; Galstyan, Piskopos Stepanos Vakayinamesi, s. 66.

${ }^{58}$ Kartlis Tskhovreba/Dmitri Gamq'relidze, s. 331; Brosset, Histoire de la Géorgie, s. 516; Kiragos, Moğollar, s. 33, 34.

59 Allen, A History of The Georgian People, s. 113.

${ }^{60}$ Kartlis Tskhovreba/Dmitri Gamq'relidze, s. 332.
}

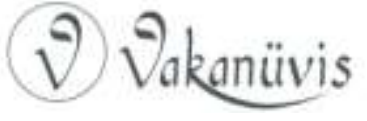


etmekte olan Gürcistan Kraliçesi'nin yanına Kutaisi'ye kaçmakta buldu. Avak firar edince Moğollar önemli bir müttefikten ve onun yardımlarından mahrum kalmışlardı. Hemen haber gönderip Avak'ın kendilerinden ayrılmamasını bildirdiler. Avak ise Kaan'a itaatinden feragat etmediğini ancak öldürülmekten korktuğu için kaçtığını bildirdi. Moğollar yaptıkları aramalar sonucunda Avak'ın saklandığı kaleyi buldular ve ona yeniden haber gönderip geri dönmesini istediler. $\mathrm{Bu}$ isteği kabul eden Avak, ordugâha avdet eder etmez kendisine Kaan'dan gelen bir emir doğrultusunda her yere korkusuzca ve serbestçe gidebileceğine dair teminat verildi. Kısa zaman içinde başta Atabeg Avak olmak üzere Şehinşah, Vahram ve İvane Cakeli gibi komutanların Moğollar ile anlaşarak ülkenin büyük bir bölümünü onların hâkimiyetine terk ettiler. Bu sırada Atabeg Avak'ın yardımları sayesinde Kraliçe Rusudan ile yapılan bir barış anlaşmasının sonucunda Moğollar Tiflis, Samşvilde, Kartli ve Samtskhe Bölgeleri'nin tamamını Kraliçe'nin oğlu David'e verdiler ve Narin David olarak adlandırdıkları bu prensi, kral olarak tanıdılar. ${ }^{61}$

Gürcüler ile Moğollar arasındaki ilişkilerin teşkil edilmesi sürecinde iki taraf açısından da çözülmesi zor olan bütün sorunların üstesinden gelinmesinde en önemli rolü üstelenen Atabeg Avak, kısa zaman sonra yeniden bir Gürcü-Moğol anlaşmazlığı ile karşı karşıya kaldı. Ancak bir yanlış anlaşılmadan ibaret olan bu mevzuyu Gürcülerin lehine çözdükten sonra 1250 yılında öldü. ${ }^{62}$ Avak öldüğünde erkek evladı yoktu ve eşi Gonca'dan (Gvantsa-Gonts) olma Khuashak (HvaşagHuşek-Hoshak) isimli bir kızı vardı. ${ }^{63}$

\section{Mankaberdeli (Mengü-Berdi) Ailesi}

Atabeg Avak, Gürcü tarihine yön veren önemli olayların cereyan ettiği Moğol istilası döneminde 23 yıl Atabeglik makamında oturdu. Atabeg unvanını kullanan ve bu makamın gücünden ziyadesiyle yararlanan ayrıca kendilerine sunmuş olduğu imtiyazları hiç çekinmeden kullanan Mkhargrdzeli ailesine mensup olup da bu unvanı

\footnotetext{
${ }^{61}$ Kartlis Tskhovreba/Dmitri Gamq'relidze, s. 334; Brosset, Histoire de la Géorgie, s. 521.

${ }^{62}$ Gürcülerin bu dönemde meydana gelen ilk isyan teşebbüsleri ve Atabeg Avak'ın rolü hakkında geniş bilgi için bkz. Subaşı, Gürcü-Moğol, s. 73-75.

${ }^{63}$ Stepannos Orbelean/Bedrosian, s. 212.
}

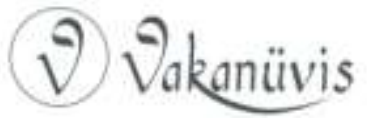


kullanan son kişi Avak idi. Avak'ın erkek çocuğu olmaması unvanın aile içindeki devamını engellemiş ve uzun bir süre yani Sadun Mankaberdeli'nin Atabeg olarak atandığı tarihe kadar Atabeglik müessesesi Güney Kafkasya coğrafyasında derin bir sessizliğe bürünmüştür.

Gürcü siyasî yapısında yeni oluşumların meydana geldiği bir dönemde bu defa bir atama usulü ile Tiflis'te tam da Gürcü Kral'ın yaşının küçük olması hasebiyle İlhanlı hükümdarı tarafından bir Atabeg tayin edildi. Kafkaslardaki yeni atabeg ailesinin ortaya çıkmasına sebebiyet veren asıl kişi bizzat Tiflis merkezli Gürcistan Krallığı'nın yöneticisi Kral Ulu David'dir. Gürcü Kral Ulu David, Avak'ın ölümünden sonra onun dul eşi Gonca ile evlendi. Ardından Avak'ın sahip olduğu bölgelerin tamamını kızı Khuashak'ya bırakıp onu Sadun Mankaberdeli'nin gözetimine verdi ve idareyi de Sadun'a emanet etti. İşte bu tayin veya atama Gürcü siyasî hayatında yeni bir oluşumun ayak sesleriydi. Çünkü Sadun; akıllı, makul, anlayışlı, cömert ve hırslı bir adam ayrıca iyi bir okçuydu. $O$, kendisine verilen yeni görevin hemen ardından Hülagu'nun yanına gitti. Kaan'ın elini öpüp boyun eğen Sadun, ona güzel sözler söyleyerek itaatini bildirdi. Sadun, sarf ettiği güzel sözlerle etkilemeyi başardığı Hülagu'nun gözdesi oldu. Bu andan itibaren Sadun'un yükselişi başlamış oldu. Kral Ulu David de Sadun'un gücünün farkında olduğu için ona büyük önem verir ve saygı gösterirdi. Kral ayrıca Avak'ın sahip olduğu bölgelerin idaresini de Sadun'a emanet etti. ${ }^{64}$ Gürcüce, Moğolca, Ermenice ve Farsça bilen Sadun, çağının aranan adamıydı. $O$, Moğollara karşı sempati besleyip onların dilini ve adetlerini bilerek güzel sözler söyleyerek Hülagu'nun güvenini kazanmış ve itibar görmeye başlamıştı. Atabeg Avak'ın kızı Khuashak'ın saltanat naibi olan Sadun, Khuashak'ın, Hülagu'nun Sahib Divan olarak görevlendirdiği Şemseddin Muhammed Cüveynî ile evlenmesi üzerine önlenemez yükselişine devam etti. ${ }^{65}$ Hülagu'dan olduğu gibi Abaka

\footnotetext{
${ }^{64}$ Kartlis Tskhovreba/Dmitri Gamq'relidze, s. 351.

${ }^{65} \mathrm{Bu}$ dönemde Atabeg'in şahıs ismi olarak kullanımına da rastlamak mümkündür. Şemseddin Muhammed Cüveynî, eşi Khuashak Hatun'dan olan oğluna Atabeg ismini veriştir. Ayrıca coğrafyanın önemli yöneticilerinden birisi olan Celal Hasan'ın da Atabeg isimli bir oğlu olduğu bilinmektedir. Reşîuüddin Fazlullah, Câmiu't-Tevârih, (illhanlılar Kısmı), Çev.: İsmail Aka, Mehmet Ersan, Ahmad Hesamipour Kelejani, TTK Yay., Ankara 2013, s. 155; Kartlis Tskhovreba/Dmitri Gamq'relidze, s. 359; Stepannos
} 
tarafından da saygı ve hürmet gören Sadun'u, Sahib Divan Şemseddin de eşi Khuashak'ın kapıcısı ve temsilcisi olarak görevlendirerek, ona iyi niyet gösterdi. Bu sırada Kral Ulu David de Sadun'a çok sayıda arazi verdi. ${ }^{66}$ Abaka tarafından sevildiği için Sadun, bütün Gürcistan mtavarilerinin üstünde bir makama yükselmişti. Sadun, mevkisinin kendisine verdiği öz güvenle ve eşini temsil etme hakkı ile Tamara'nın da isteği doğrultusunda Gürcistan işleri ile ilgilenmeye başladı.

Gürcistan'da kralsız geçen ve kargaşa ile devam eden bu süreç Abaka Han'ı 1272 yılında Gürcistan'a yeni bir kral tayin etmeye sevk etti. Gürcistan tahtı için en uygun aday, uzun zamandır rehine olarak IIlhanlı sarayında bulunan ve müteveffa Kral Ulu David'in oğlu Demetre idi. Gürcü yöneticiler, Kral II. Demetre'nin otağına gelip Şehinşah'ın oğlu İvane'nin etrafında birleştiler. Ardından Şehinşah, II. Demetre'yi, Abaka Han'a götürdü ve takdim etti. Abaka onu çok iyi karşıladı ve onun dostluğuna şahitlik etti. Sargis Cakeli'nin özel mülkleri ile idari bölgeleri dışında müteveffa krala ait olan kralığının tamamını genç prens Demetre'ye verdi. II. Demetre (1271-1289) 1271-72'de Gürcü tahtına çıktı. ${ }^{67}$ Ancak II. Demetre'nin henüz küçük olması ve ülkeyi yönetecek güce sahip olmaması nedeni ile yeni Kral'a bir vasi tayin etmek gerekiyordu. Gürcistan işlerini takip etmesi ve düzenlemesi için Abaka tarafından Kral'a eşlik etmesi amacıyla Sadun Mankaberdeli (Mengü-Berdi) danışman olarak görevlendirildi. 1272 yılında Kaan ile görüşen Sadun'a "Atabeg" unvanı verildi. Kral, Tiflis'e vardıktan sonra babasının mülküne yerleşti. ${ }^{68}$ Abaka, Sadun'a atabeg unvanı vererek

Orbelean/Bedrosian, s. 215; Subaşı, Gürcü-Moğol, s. 54; Atabeg'in şahıs ismi olarak kullanımı ilerleyen dönemlerde de gelişerek devam etmiştir. Geniş bilgi için bkz. Sinan Uyğur, "1595 Tarihli Defteri-i Mufassal-ı Ahıska'daki Türkçe Kökenli Kişi Adları Üzerine", IBAD-2017 2. Inernational Scientific Recearches Congress on Humanities and Social Sciences, İstanbul 20-23 Nisan 2017.

${ }^{66}$ Kartlis Tskhovreba/Dmitri Gamq'relidze, s. 362.

67 Stepannos Orbelean/Bedrosian, s. 217; Galstyan, Sebastatsi Vakayinamesi, s. 52Piskopos Stepanos Vakayinamesi, s. 71; Alexander Mikaberidze, Conflict and Conquest in the Islamic World: A Historical Encyclopedia, S.Barbara, Californla, Oxford, 2011, s. 263.

${ }^{68}$ Kartlis Tskhovreba/Dmitri Gamq'relidze, s. 368; Brosset, Histoire de la Géorgie, s. 586; Bertold Spuler, Iran Moğolları, Siyaset, Idare ve Kültür, IIhanlılar Devri, 12201350, Çev.: Cemal Köprülü, Ankara 1957, s. 84.

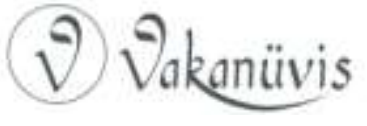


bölgedeki nüfuzunun artmasını sağladı. ${ }^{69}$ Kısa zamanda Gürcü coğrafyasının en güçlü insanlarından birisi haline gelen Atabeg Sadun, nüfuzunun ona sağladığı güçle büyük bir servet sahibi oldu. ${ }^{70} \mathrm{Bu}$ sırada II. Demetre, kral olarak Tiflis'e geldiğinde hâkimiyetini kuvvetlendirmek istemesine rağmen Abaka'nın Sadun'u yüksek bir rütbeye tayin etmesi, Kral'ı, Atabeg Sadun'un ellerine bırakmıştı. Sadun, başta Telavi ve Belakani olmak üzere Kral II. Demetre'nin elinden pek çok bölgeyi aldı. $O$, gerek büyük noyanlar gerekse Moğol idareciler tarafından hiçbir şiddet ve kanunsuzluğa maruz kalmadığı için Gürcistan işlerini mükemmel bir şekilde idare etti. Gürcistan onun sayesinde gelişti. ${ }^{71}$ Moğollar, Kral II. Demetre'den birikmiş borçların ödenmesini talep ettiğinde Moğolların merkezinde bulunan Kral, Atabeg Sadun'dan bu borçlarını kapatmasını istedi. Sadun ise "Eğer bana Dmanisi'yi verirsen Kaan'a borçlarını öderim." dedi. Kral, Sadun'u dinledikten sonra teklifini kabul etti ve borçları karşılığında Dmanisi ve Kars ile birçok yerin yönetimini ona teslim etti. Atabeg Sadun, uzun süre Kral II. Demetre'ye hizmet etti. Ayrıca görevde olduğu süre boyunca bir ordu ile altın ve gümüşten müteşekkil büyük bir hazine, eşi görülmemiş bir sürü ve sınırsız mal varlığına sahip oldu. Atabeg Avak'ın yurdu, ${ }^{72}$ Sadun'a ve Sahib Divan Şemseddin'in eşi olan Khuashak'a aitti ve bundan dolayı da Abaka Kaan ve Sahib Divan Şemseddin, Sadun'un tavsiyelerine önem verir; sözlerine itibar ederlerdi. Sahib Divan ve Sadun, Kaan'ın değer verdiği kişiler arasındaydı. Sadun kısa zaman içinde Kars'a yerleşti ve kurnazlığı ile sınır komşusu olan Akhaltsikhe'den (Ahıska) toprak elde edip Akhaltsikhe yöneticisinin kızını da kendisine eş olarak aldı. Kaan, Gürcistan ordularının yönetimini ona verdi. Bundan sonra Atabeg Sadun, Gürcistan'ı ve

\footnotetext{
${ }^{69}$ Kartlis Tskhovreba/Dmitri Gamq'relidze, s. 368.

${ }^{70}$ Piskopos Stepanos'a göre Atabeg Sadun ve eşi Tamara 1282 'de ölmüşler ve Kral II. Demetre bu ölümlerden sonra büyük bir teessüre kapılmıştır. Galstyan, Piskopos Stepanos Vakayinamesi, s. 74; Allen, A History of The Georgian People, s. 118; Nikoloz Berdzenişvili - Simon Canaşia, Gürcistan Tarihi (Başlangıçtan 19. Yüzyıla Kadar), Çev.: Hayri Hayrioğlu, Sorun Yayınlar, İstanbul 2000, s. 183.

${ }^{71}$ Kartlis Tskhovreba/Dmitri Gamq'relidze, s. 369.

72 Stepannos Orbelean'a göre Avak'ın yurdu olarak belirtilen yerler Bütün Ermenistan, Şehinşahların hâkim olduğu coğrafyalar ile 1282 yılında ölen Atabeg Sadun'un oğullarının yani Kutluğ Buka'nın ve Gag Prenslerinin hâkimiyet sahasıdır. Stepannos Orbelean/Bedrosian, s. 217; Stéphanos Orbélian/Brosset, s. 238
}

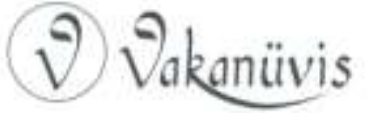


Ermenilerin iskan edildiği yerleri Kral ile birlikte idare etti. Sadun, eşi Tamara ile beraber 1282 yılındaki ölümüne kadar Kars'ta hayatlarını sürdürdüler. ${ }^{73}$ Atabeg Sadun'un ölümünün ardından Kral II. Demetre, Sadun'un oğlu Kutluğ Buka'yı onun yerine getirmeyi uygun buldu. Ancak ona Atabeg yerine yalnızca Başkumandan unvanı verdi. Bu, Kutluğ Buka için tenzili rütbe anlamına gelmekteydi. ${ }^{74}$

Ancak kısa zaman sonra talih Başkumandan Kutluğ Buka'ya gülmeye başladı. Kral II. Demetre'nin 1289 Mart ayının 23'ünde Argun Han (1284-1291) tarafından idam ettirilmesi Gürcistan'da siyasî otoritenin tamamen kaybolmasına sebebiyet vermişti. ${ }^{75}$ Yaşananlar sonrası hemen harekete geçen Argun, Kral'ın idam edilme sürecinde faal olarak olayların içerisinde yer alan Kutluğ Buka ile yeni atanacak kral hakkında istişare etmeye başladı. Kutluğ Buka'nın teklif ve telkinleri sonucunda Narin David'in oğlu Vakhtang'da karar kılan Argun Kaan, II. Vakhtang'a (1289-1292) Doğu Gürcistan tarafının yönetimini verip onu kral olarak tahta çıkardı. Kral II. Vakhtang, kendisine krallık yolunu açan Kutluğ Buka'yı ödüllendirmek amacıyla onu Gürcistan ordularının başına getirdi ayrıca bir süredir Gürcistan'da kullanılmayan Atabeglik unvanını Kutluğ Buka'ya tevzi edip aynı anda Başkumandan unvanı ile krallığı yönetme hakkı verdi. ${ }^{76}$

Gürcistan'da yönetici değişikliği konusunda İlhanlılara öncülük ederek devlet merkezi ile devamlı iyi ilişkiler kuran Atabeg Kutluğ Buka, bu süreçte Argun tarafından muteber bir şahıs olarak görülmüş ve sözüne her daim itibar edilmiştir. Ancak bu durum fazla uzun sürmedi ve Geyhatu (1292-1295) döneminde Atabeg Kutluğ Buka gözden düşmeye başladı. Devamında Geyhatu H. 692 yılının Şaban ayının sonlarına doğru (Temmuz-Ağustos 1293) İşkemer'de konakladığı bir

\footnotetext{
${ }^{73}$ Kartlis Tskhovreba/Dmitri Gamq'relidze, s. 370; Berdzenişvili - Canaşia, Gürcistan Tarihi, s. 183; Galstyan, Piskopos Stepanos Vakayinamesi, s. 74; Allen, A History of The Georgian People, s. 118.

${ }^{74}$ Kartlis Tskhovreba/Dmitri Gamq'relidze, s. 374.

${ }^{75}$ Spuler, IranMoğolları, s. 95.

${ }^{76}$ Kartlis Tskhovreba/Dmitri Gamq'relidze, s. 379, 380; Brosset, Histoire de la Géorgie, s. 607; Galstyan, Piskopos Stepanos Vakayinamesi, s. 80; Mikaberidze, Historical Dictionary of Georgia, s. 649.
}

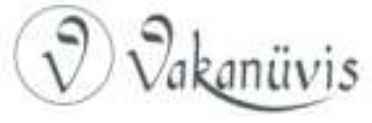


sırada bilinmeyen bir nedenden dolayı Atabeg Sadun'un oğlu Atabeg Kutluğ Buka'yı yasaya çarptırdı. ${ }^{77}$

\section{Cakeli Hanedanı}

Atabeg olarak bir süre görev yapan Kutluğ Buka'nın ölümünün ardından Güney Kafkasya siyasî hayatında Atabeglik müessesesi yeniden sessizliğe büründü. Ancak Abaka Kaan'ın Altın Orda Hükümdarı Berke ile giriştiği savaşlarda büyük yararlılıklar göstermesinin akabinde Sargis Cakeli ve ailesinin sahip olduğu Samtskhe bölgesini Gürcü krallığından ayırarak doğrudan Moğol yönetimine bağlaması yeni ve daha güçlü bir yapı ortaya çıkardı. ${ }^{78} \mathrm{Bu}$ dönemde Tiflis merkezli Gürcü hâkimiyet sahasından koparılıp tamamen İlhanlı merkezine bağlanan Samtskhe-Saatabago'da Cakeli (Jakeli- ‘ugymo) ailesinin hızlı ve önlenemez yükselişi başladı. Sargis ve oğlu Beka kısa zaman içerisinde Tasiskari, Karnukalaki, Samtskhe, Acara, Şavşat, Klarceti, Göle, Karnipor, Valarşavan, iki Artan, Nigal Deresi, Tao'nun büyük bir bölümüne ve Javakheti'nin çok sayıdaki köyüne sahip oldu. Abaka'ya hizmetleri karşılı̆ında ondan aldıkları yardımlarla ve Kral II. Demetre'nin emri altında kaldıkları süre boyunca bu baba ve oğlun güçleri gittikçe arttı. ${ }^{79}$ Sargis'ten sonra oğlu Beka 1308 yılına kadar kendisine miras kalan yerleri idare etti. Gürcistan kralı III. Vakhtang'ın 1307/8'deki ölümünden hemen sonra aynı yıl içerisinde Samtskhe yöneticisi Beka da öldü. Beka'nın ardından ülkesi Sargis, Kvarkvarye ve Şalva isimli üç oğlu arasında bölündü. ${ }^{80}$ Babasından sonra büyük oğul olmasından dolayı Saatabago'nun önemli bir kısmını idare etmeye başlayan II. Sargis Cakeli (1308-1334)

\footnotetext{
${ }^{77}$ Reşîdüddin Fazlullah/İsmail Aka, s. 181; Fahruddin Ebu Süleyman Davud b. Tacuddin Fahr-i Benâketî, Târîh-i Benâketî (Ravzat ûlî'l-elbâb fi ma'rife't -tevârîh ve'l-enisâb), Neşr.: Cafer Şiar, Çaphane-i Daverpenah, Tahran 1343 (1969), s. 448; Fasîh-i Hâfî, Mücmel-i Fasîhî, C. II., s. 366.

${ }^{78}$ Kartlis Tskhovreba/Dmitri Gamq'relidze, s. 361.

${ }^{79}$ Kartlis Tskhovreba/Dmitri Gamq'relidze, s. 370; Brosset, Histoire de la Géorgie, s. 590.

${ }^{80}$ Kartlis Tskhovreba/Dmitri Gamq'relidze, s. 394; Brosset, Histoire de la Géorgie, s. 641.
} 
Atabeglik unvanını kullanmaya başladı. ${ }^{81}$ Aslında babası Beka, Abaka

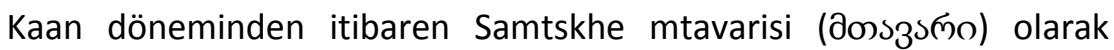
bilinirken hiçbir zaman Atabeg olarak anılmadı. ${ }^{82}$ Cakeli ailesinden önce Mkhargrdzelilerden Atabek ivane ve oğlu Avak ile Mankaberdelilerden (Mengü-Berdi) Atabeg Sadun ile oğlu Kutluğ Buka'nın Atabeg unvanını kullanması babadan oğula geçen bu yapının Güney Kafkasya tarihinde yüzlerce yıl sürecek bir siyasî teşkilatın ortaya çıkmasına ön ayak olmuştu. Her ne kadar bu iki aile içinde atabeglik serüveni kısa sürmüş olsa da II. Sargis Cakeli'nin Atabeglik kurumunu yeniden hayata geçirmesi Güney Kafkasya'da özellikle de Atabegler Yurdu olarak bilinen bölgelerde Tiflis merkezli yönetimin baskılarından uzak, yüzlerce yıl sürecek yöresel bir gücün var olmasını sağlamıştır.

İlhanlı hâkimiyeti altındaki Kafkaslarda uzun süreler Altın Orda ile mücadeleler yapılmış olsa da XIV. yüzyılın ilk çeyreğinden itibaren Illhanlıların güç kaybetmeye başlaması Gürcü Kralı V. Parlak Giorgi'nin işine yaradı. İlhanlıların son büyük emiri Çoban'ın ölümünün (1327) ardından geriye kalan devlet adamları ve askerî sınıf, küçük yaşta olmasından dolayı Ebû Saîd'den gitgide uzaklaştılar. Emirlerin bir kısmı İran'a, Horasan'a, Irak'a ve Azerbaycan'a bir kısmı da Anadolu topraklarına gitti. Bu sırada V. Giorgi, idaresi altında olan Gürcistan bölgesini, bazen para ile bazen de silah kullanarak Moğollardan temizledi. Özellikle de Kartli'dekiler başta olmak üzere bütün eristavileri ${ }^{83}$ hâkimiyeti altına aldı. Kral, bölgeyi güvenlik altına aldıktan sonra Derbend'e kadar bütün coğrafyayı Gürcü hâkimiyetine sokmayı

81 Brosset eserinde II. Sargis Cakeli'nin atabeg unvanını kullanmasına açıklama yaparken Kraliçe Tamara ve Giorgi Laşa döneminde devletin en kudretli şahsiyetlerinden birisi olan Atabeg İvane Mkhargrdzeli'yi Sargis'in büyük atası olarak ifade etmiştir. Ancak bilinmektedir ki Mkhargrdzeli ailesi ile Cakeli aileleri farklı iki menşei ye mensuptur ve Atabeg İvane ile Sargis Cakeli'nin atası Samtskhe'nin yöneticisi İvane Cakeli farklı kişilerdir. Brosset, Histoire de la Géorgie, s. 647, d. not. 1.

${ }^{82}$ Kartlis Tskhovreba/Dmitri Gamq'relidze, s. 373, 386.

83 Eristavi, Gürcüce eri-eris (ordu, daha sonra halk anlamında da kullanılmaya başlamıştır) vetáai (baş) kelimelerinin birleştirilmesiyle oluşmuştur ve zamanla mahalli idareci anlamında kullanılmıştır. Ayrıca büyük bir orduya hükmeden ve belli bir eyalete sahip olan şahıslara verilen isimdir. İbrahim Tellioğlu, XI-XIII. Yüzyıllarda Türk-Gürcü ilişkileri, Serander Yay., Trabzon 2009, s. 12; Allen, A History of The Georgian People, s. 237; Mikaberidze, Historical Dictionary of Georgia, s. 287.

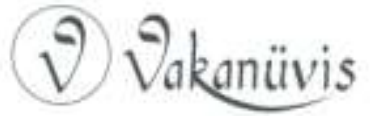


başardı. Ardından V. Giorgi, Atabeg II. Sargis'in yanına giderek onunla anlaşıp bütün grupları yeniden bir araya topladıktan hemen sonra hiçbir direnişle karşılaşmadan Arran Bölgesi'ne girdi. Devamında Şirvan'a geçti ve oradan da Tiflis'e geri döndü. Aslında bu girişim Gürcü siyasî birliğinin yeniden teşkil edilmesi açısından büyük öneme sahiptir. ${ }^{84}$ Ancak her ne kadar Tiflis merkezli idareye dâhil edildikleri ifade edilse de Atabeg Yurdu'nun idareci sınıfı Atabeglik unvanını kullanmayı hiçbir zaman bırakmamış ve bu müessese babadan oğula geçerek uzun yıllar bölgedeki siyasi hayatındaki yerini korumuştur. 1334 'te Samtskhe'de Atabeg II. Sargis öldükten sonra Kral V. Giorgi, II. Sargis'in oğlu Kvarkvarye'yi babasının makamına oturtarak ona Atabeg unvanı verdi. Ardından Klarceti, İspir, Kalmaki, Ardanuç ve Ardahan ile Samtskhe Bölgesi'ne kendi adına Atabeg Kvarkvarye'nin amcası ve kuzenleri olan eristavileri yerleştirerek bu bölgeleri merkeze bağladı. ${ }^{85}$

\section{Sonuç}

Selçuklu devlet teşkilatının vazgeçilmez bir müessesesi olan atabeglik, faal olarak kullanıldığı ilk zamanlardan itibaren devletin gelişmesine ve büyümesine önemli katkılarda bulunmuş, idarî ve mülkî mevzuların hızlı bir şekilde nihayete ermesini sağlamıştır. Nizamülmülk'ün atabegliği ile başlayan süreç kısa zamanda siyasî yapının vazgeçilmez bir öğesi olmuş ve Selçuklu coğrafyasının her köşesinde kendini göstermiştir. Selçuklu Devleti'nin en güçlü dönemlerinde Dımaşk, Kirman ve Musul Atabeglikleri yarı bağımsız bir şekilde faaliyet gösterirken bu siyasi oluşumlar, Sultan Sencer'in ölümü ile tam bağımsız bir hal alarak hayatlarına devam etmişlerdir. Selçukluların gölgesinde ortaya çıkan bu atabegliklerden başka, farklı bölgelerde kurulmuş olan Türkiye Selçukluları, Irak ve Horasan Selçukluları, Eyyûbiler hatta Atabegü'l-asâkir ${ }^{86}$ ismiyle çok mühim bir makamın bulunduğu Memlûkler de dâhil pek çok devlette atabeglik kurumunu görebilmekteyiz. Selçuklular kendinden sonra gelen Türk

\footnotetext{
${ }^{84}$ Brosset, Histoire de la Géorgie, s. 646, 647.

${ }^{85}$ Brosset, Histoire de la Géorgie, s. 647, 648.

${ }^{86}$ Atabegü'l-asâkir, Memlûk orduları başkumandanı olup Sultan'dan sonra ordunun sevk ve idaresinin sorumlu olan şahsa verilen unvandır. Ahmet Sağlam, "Ortaçağda Orijinal Bir Siyasi Yapı: Güçlü ve Nüfuzlu Her Emir Sultan Olur," Uluslararası Sosyal ve Eğitim Bilimleri Dergisi, C.2. S. 4 Aralık 2015, s. 117.
}

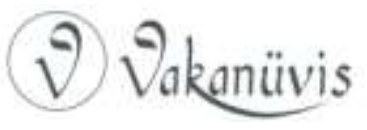


topluluklarını etkilediği gibi devamlı iletişimde ve etkileşimde olduğu Hristiyan toplum ve devletlerini de derinden etkilemiştir. Bunların başında gelen Kafkaslardaki bölgesel Gürcü Krallığı'nın siyasî yapısında Selçuklu izlerine rastlamak bu etkileşimin doğal bir sonucudur.

Selçuklularda şekillenmiş olan atabeglik müessesesi Gürcistan Güney Kafkasya siyasî hayatına Mkhargrdzeli ailesinden İvane'nin 1212 yılında Tamara tarafından atabeg olarak atanması ile giriş yapmıştır. Atabeg ivane 1227 yılındaki ölümüne kadar bu makamda kalırken onun ölümünün ardından oğlu Avak, atabeg olarak atanmış ve Gürcü tarihinin belki de en karanlık yıllarında bu makamı Moğol baskısı altında yaşatmaya gayret etmiştir. 1250 yılında Atabeg Avak'ın arkasında erkek bir çocuk bırakmadan ölümü Mkhargrdzeli ailesi için atabeglik serüvenlerinin sonu demektir. Böylece atabeglik müessesesi 1272 yılına kadar Güney Kafkasya'da derin bir sessizliğe büründü. Ta ki Abaka Han'ın Sadun Mankaberdeli'yi Gürcü Kral II. Demetre'ye atabeg olarak görevlendirmesine kadar. Atabeg Sadun ve ardından oğlu Kutlug Buka'nın idamına kadar geçen sürede Gürcü coğrafyasında faaliyet gösteren Mankaberdeli ailesinden sonra Samtskhe bölgesinin yönetici sınıfını oluşturan Cakeli ailesinden II. Sargis 1308'de atabeg unvanını kullanmaya başladı. Yüzyılı aşkın bir süre içerisinde Güney Kafkasya coğrafyasında bir Selçuklu mirası olan atabeglik kurumu bütün siyasî vakalarda etkisini hissettirmiştir.

\section{Kaynakça}

Aknerli Grigor, Okçu Milletin Tarihi, Çev.: Hrand D. Andreasyan, Yeditepe Yay., İstanbul 2007.

Alaaddin Ata Melik Cüveynî, Tarih-i Cihan Güşa, Çev.: Mürsel Öztürk, Kültür Bakanlığı Yay., Ankara 1999.

Alptekin, Coşkun, "Atabeg", C. I., DíA., s.38-40.

Alptekin, Coşkun, "Selçuklu Devletinin Askeri Teşkilatının Eyyubi Devleti Askeri Teşkilatına Tesiri", Belleten LIV, S. 209, Ankara 1990, s. 118.

Allen, W.E.D., A History of The Georgian People, London 1932.

Bedrosian, Robert, Het'um the Historian's History of the Tartars, [The Flower of Histories of the East] compiled by Het'um the Armenian of the

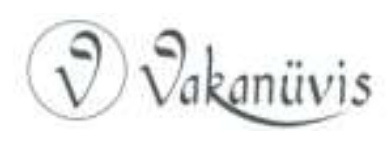


Praemonstratensian Order Translated by Robert Bedrosian, Long Branch, New Jersey, 2004, Capter 18.

Benâketî, Fahruddin Ebu Süleyman Davud b. Tacuddin Fahr-i Benâketî, Târîh-i Benâketî (Ravzat ûlî'l-elbâb fi ma'rife't -tevârîh ve'l-enisâb), Neşr.: Cafer Şiar, Çaphane-i Daverpenah, Tahran 1343 (1969.

Berdzenişvili Nikoloz - Simon Canaşia, Gürcistan Tarihi (Başlangıştan 19. Yüzyıla Kadar), Çev.: Hayri Hayrioğlu, Sorun Yayınlar, İstanbul 2000.

Bezer, Gülay Ügün, “Şemseddin İldeniz 1148-1175”, i.A. C.22, s. 81-82.

Broadhurst, R.J.C., A History of the Ayyubid Sultans of Egypt, Translated from the Arabic of al Maqrizi, Boston 1980.

Brosset, Marie F., Histoire de la Géorgie, S.Petersbourg 1849.

Brosset, Marie F., Gürcistan Tarihi, (Eski Çağlardan 1212 yılına Kadar), Çev.: Hrand D. Andreasyan, Not./Yay.: Erdoğan Merçil, TTK. Yay., Ankara 2003.

Bünyadov, Ziya, Azerbaycan Atabegleri Dövleti, 1136-1225, Bakü 2007.

Cüzcani, Ebu Ömer Minhacüddin Osman b. Muhammed el-Cüzcani, Tabakat-ı Nasıri: from A.H. 194 (810 A.D.) to A.H. 658 (1260 A.D.) / Maulana Minhaj-ud-din Abu-Umar-I-Usman; translated by Major H. G. Raverty, New Delhi 1970.

Cûzcânî, Ebû Ömer Minhacüddin Osman b. Muhammed b. Osman Cûzcânî, Tabakât-ı Nâsırî -Tarih-i Iran ve islam-660/1262, C.II., Tsh.: Abdülhay Habîbî, Dünya-yı Kitab, Tahran 1984.

D’ohsson, M. Baron C., Moğol Tarihi, Çev./Yay./Haz.: Ekrem Kalan-Qiyas Şükürov, İstanbul 2006.

Erdoğan, Coşkun, Hârezmşâh Alâeddin Muhammed Dönemi Siyasi Tarihi (1200-1220), Yayınlanmamış Doktora Tezi, AÜSBE, Erzurum 2015.

Fasîh Ahmed b. Celaleddin Muhammed Hâfî, Mücmel-i Fasîhî, C. II., Neşr.: Muhammed Ferruh, Meşhed 1340 (1961).

Galstyan, A.G., Ermeni Kaynaklarına Göre Moğollar, (Mhitar Ayrivanetsi Vakayinamesi) Çev.: Ilyas Kamalov, Yeditepe Yay., İstanbul 2005.

Gök, Halil Ibrahim, Musul Atabeyliği Zengiler (Musul Kolu 1146-1233), TTK. Yay., Ankara 2013.

Gömeç, Saadettin Yağmur, Türk Tarihinde Çingizliler, Ankara 2017.

Gregory Abû'l Farac, Abû'l-Farac Tarihi, C.II., Süryaniceden Çev.: Ernest A. Wallis Budge, Türkçe Yay.: Ömer Rıza Doğrul, TTK. Yay., Ankara 1999.

Histoire Chronologique, par Mkhithar D'airivank, XIII-S.,Traduite de L'armenien, Par Marie F. Brosset, St-Petersbourg 1869.

İbnü'l-Esîr, El Kâmil fi't-Tarih, C.X., (Terc. Heyet: Ahmet Ağırakça, Beşir Eryarsoy, Zülfikar Tüccar, Abdulkerim Özaydın, Yunus Apaydın, Abdullah Köşe), Hikmey Neşiryat, İstanbul 2016.

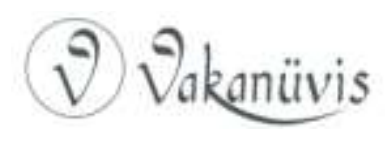


İbn Kesîr, El Bidâye Ve'n-Nihâye, C.XIII., Çev.: Mehmet Keskin, Çağrı Yay., istanbul 1985.

Jackson, Peter, The Mongols and The West, 1221-1410, Great Britain 2005.

Kartlis Tskhovreba, (A History of Georgia), Trans.: Dmitri Gamq'relidze, Ed.: Roin Metreveli and Stephen Jones, Georgian National Academy of Sciences, Artanuji Publishing, Tbilisi 2014.

Kayhan, Hüseyin, "Azerbaycan Atabeyleri IIdenizlilerin Yıkılışı", Tarih ve Gelecek Dergisi, Nisan 2017, C. 3, S. 1., ss. 239-255.

Kayhan, Hüseyin, "Irak Selçukluları (1120-1194)", Yeni Türkiye, Ortadoğu Özel Sayısı III, C.3, S. 84, Ocak-Haziran 2016, s.73-84.

Kırzıoğlu, M. Fahrettin, Yukarı-Kür ve Çoruk Boyları'nda Kıpçaklar, TTK. Yay., Ankara 1992.

Kirakos Gandzakets'i's, History of the Armenians, Trans.: Robert Bedroisan, New York 1986.

Köprülü, M. Fuad, “Ata”, C. I. I..A., MEB. Yayınları, s. 711-718.

Köse, Bayram Arif, "Moğol İstilasının Güney Kafkasya Şehirleri Üzerinde Idarî ve iktisadî Etkileri", Uluslararası Sosyal Araştırmalar Dergisi, C.8. S. 41. 2015.

Mehmetov, İsmail, Türk Kafkası'nda Siyasi ve Etnik Yapı, Eski Çağlardan Günümüze Azerbaycan Tarihi, İstanbul 2009.

Merçil, Erdoğan, Fars Atabegleri Salgurlular, TTk. Yay. Ankara 1991.

Mikaberidze, Alexander, Conflict and Conquest in the Islamic World: A Historical Encyclopedia, S.Barbara, Californla, Oxford, 2011.

Mikaberidze, Alexander, Historical Dictionary of Georgia, Toronto 2007.

Minorsky, V., Studies in Caucasian History, London 1953.

Mîrhând, Mîr Muhammed b. Seyyid Burhaneddin Havendşah Mîrhând, Târîh-i Ravzatü's-Safâ Fi Sireti'l-Enbiyâ ve'l-Mulûk ve'l-Hulefâ, 903/1498, C. V Müessese-i Hayyam ve İntişarat-ı Piruz, Tahran 1339.

Müverrih Kiragos, Ermeni Müverrihlerine Göre Moğollar, Terc.: Gürsoy Solmaz, Ankara 2009

Müverrih Vardan, Türk Fütuhatı Tarihi, (889-1269), Çev.: Hrand D. Andreasyan, I.Ü.E.F.Y. Tarih Semineri Dergisi, C.I., Sayı: 2, İstanbul 1937.

Özaydın, Abülkerim, Sultan Muhammed Tapar Devri Selçuklu Tarihi (498511/1105-1118), TTK Yay.; Ankara 1990, s. 136,137.

Reşîüddîn Fazlullâh-i Hemedânî, Câmi'u't-tevârîh -718/1318-, C. I., Yay. Haz.: Behmen Kerimî, İntişarat-ı İkbal, Tahran 1362/1983.

Reşideddin Fazlullah, Câmi'ü't Tevârîh, C.II., Trans.: W.M. Thackston, Harvard Üniversitesi 1998.

Reşîdüddin Fazlullah, Câmiu't-Tevârih, (ilhanlılar Kısmı), Çev.: İsmail Aka, Mehmet Ersan, Ahmad Hesamipour Kelejani, TTK Yay., Ankara 2013. 
Sağlam, Ahmet, "Ortaçağda Orijinal Bir Siyasi Yapı: Güçlü ve Nüfuzlu Her Emir Sultan Olur," Uluslararası Sosyal ve Eğitim Bilimleri Dergisi, C.2. S. 4 Aralık 2015, s. 107-126.

Sevim, Ali, Suriye ve Filistin Selçukluları Tarihi, TTK. Yay., Ankara 2000.

Smbat Sparapet's Chronicle, Trans.: Robert Bedrosian, Long Branch, New Jersey 2005.

Stepannos Orbelean, History of the State of Sisakan, Trans.: Robert Bedrosian, Long Branch 2015.

Stéphanos Orbélian, Histoire de la Siounie, Trans.: Marie F. Brosset, SaintPetersbourg 1864.

Spuler, Bertold, Iran Moğolları, Siyaset, idare ve Kültür, IIhanlılar Devri, 1220-1350, Çev.: Cemal Köprülü, Ankara 1957.

Subaşı, Ömer, Gürcü-Moğol ilişkisi- Güney Kafkasya 1220-1346-, Kitabevi Yay., İstanbul 2015.

Şabânkâreî, Muhammed b. Ali b. Muhammed b. Şabânkâreî, Mecmaû'lensâb, Neşr.: Mîr Hâşim-i Muhaddis, Tahran 1376.

Şehabeddin Ahmed Nesevi, Celâlüttin Harezemşah, Çev.: Necip Asım, Devlet Matbaası, İstanbul 1934.

Şihabeddin b. Fazlullah el-ömerî, Mesâliku'l Ebsâr, -Türkler Hakkında Gördüklerim ve Duyduklarım-, Çev.: Ahsen Batur, Selenge Yay., İstanbul 2014.

Tellioğlu, İbrahim, XI-XIII. Yüzyıllarda Türk-Gürcü Ilişskileri, Serander Yay., Trabzon 2009.

Uyğur, Sinan, “1595 Tarihli Defteri-i Mufassal-ı Ahıska'daki Türkçe Kökenli Kişi Adları Üzerine", IBAD-2017 2. Inernational Scientific Recearches Congress on Humanities and Social Sciences, İstanbul 20-23 Nisan 2017.

Vassâf, Şerefeddin Abdullâh b. İzzeddin Fadlullâh b. Ebû Nuaym Yezdî Şirazî Vassâf, Tahrîr-i Târîh-i Vassâf, Neşr.: Abdul Muhammed Ayetî, Institute for Humanities an Cultural Studies, Tehran 1383/2004. 